\title{
Gender Lender: Noun Borrowings between Jingulu and Mudburra in Northern Australia
}

\author{
Rob Pensalfini \\ University of Queensland \\ r.pensalfini@uq.edu.au \\ Felicity Meakins \\ University of Queensland \\ f.meakins@uq.edu.au
}

\begin{abstract}
This paper explores borrowing of nouns between two unrelated Australian languages with a long history of contact: Mudburra, a language with no grammatical gender, and Jingulu, which has four genders and super-classing. Unusually, this case involves extensive borrowing in both directions, resulting in the languages sharing $65 \%$ of their nouns. This bi-directional borrowing of nouns allows us to simultaneously examine the behaviour of gender where (i) nouns from a language with no gender have transferred into a language with a gender system, and (ii) nouns from a language with gender have transferred into a language with no gender system. Previous work in this area has been interested in the how nouns are categorised in scenario (i) (Deuchar et al., 2014; Jake et al., 2002; Liceras et al., 2008; Parafita Couto et al., 2015; Poplack et al., 1982), and whether there is any evidence for the development of a gender system in the recipient language in scenario (ii) (Aikhenvald, 2003; Corbett, 1991; Heath, 1978; Matras and Sakel, 2007; Seifart, 2012; Stolz, 2009; Stolz, 2012). We show that Mudburra nouns borrowed into Jingulu are assigned gender on the basis of their semantics, with gender superclassing effects and morpho-phonological massaging. Some of the borrowings into Mudburra, on the other hand, demonstrate a sophisticated understanding of Jingulu morpho-syntax which speaks to a high degree of bilingualism between Mudburra and Jingulu over an extended period.
\end{abstract}

(C) ROB PENSALFINI AND FELICITY MEAKINS, 2019 | DOI:10.1163/19552629-01202007

This is an open access article distributed under the terms of the prevailing CC-BY-NC License at the time of publication. 


\section{Keywords}

noun borrowing - gender (grammatical) - bi-directional borrowing - semantic versus formal gender

Gender has been the subject of numerous studies of language contact. Most of this work has examined code-switching and borrowing contexts where noun transfer has occurred between a language which marks gender and one which does not mark gender. Some of these studies have investigated situations where nouns from a language with no gender have transferred into a language with a gender system, with a particular eye on the principle(s) underlying the gender categorisation of transferred nouns (Deuchar et al., 2014; Jake et al., 2002; Liceras et al., 2008; Parafita Couto et al., 2015; Poplack et al., 1982). Other studies have examined instances of nouns from a language with a gender system which have transferred into a language without one, and the ramifications for the recipient language, i.e. whether there is any evidence for the development of a gender system in the recipient language (Aikhenvald, 2003; Corbett, 1991; Heath, 1978; Matras and Sakel, 2007; Seifart, 2012; Stolz, 2009; Stolz, 2012). To date, all studies have examined the unidirectional transfer of nouns from one language into another. In this paper, we present a case study from northern Australia which involves large-scale bidirectional borrowing of nouns between Jingulu (Mirndi, non-Pama-Nyungan), a language with a gender system (including a superclassing system), and Mudburra (Ngumpin-Yapa, Pama-Nyungan), a language without gender.

Contact between Jingulu and Mudburra represents an unusual situation where both languages have largely maintained their native morpho-syntax, but have absorbed significant portions of the other language's lexicon. In terms of nouns, Jingulu and Mudburra share $65 \%$ of their nouns, with $32 \%$ of shared nouns originating in Mudburra and 24.5\% from Jingulu (and 43.5\% of nouns for which the direction of borrowing is cannot be determined) ( 2 ) (Meakins and Pensalfini, submitted). This level of borrowing is high, for example McConvell (2009: 795) reports that Gurindji, a language closely related to Mudburra, has borrowed $49 \%$ of its nouns, a figure which is among the world's highest (Haspelmath and Tadmor, 2009). What makes the Jingulu-Mudburra situation even more unusual is the relatively equal ratio of noun borrowings. The extent and nature of noun transfer is suggestive of high levels of sustained and balanced bilingualism, and begs the question of how bilinguals treat the 
nouns in the respective languages given that gender is only marked in one of the languages, Jingulu.

Jingulu nouns belong to one of four genders masculine, feminine, neuter and vegetable, robustly identified by concord with adjectives and demonstratives. There is also a broad semantic classification (with exceptions), with a phonological reflex, summarised in Table 1. Superclassing also affects the agreement system and categorisation of nouns which is discussed in detail in $\S 3$.

In this paper, we examine the principles underlying the gender allocation of Mudburra-origin nouns in Jingulu, i.e. the respective roles of Jingulu noun semantics and phonology on transferred Mudburra nouns, and superclassing effects $(\$ 5 \cdot 1)$. We also consider whether any parts of the Jingulu gender system (e.g. gender suffix productivity or agreement) have been 'smuggled' into Mudburra via Jingulu noun loans $(\$ 5.2)$. We begin by overviewing a method for determining direction of borrowing, i.e. Mudburra $\rightarrow$ Jingulu or Mudburra $\rightarrow$ Jingulu, using criteria independent of gender (cf. Meakins and Pensalfini, submitted) (\$2). We then introduce the gender system of Jingulu (\$3), and review previous work on noun transfer and gender $(\$ 4)$, before turning our attention to the behaviour of gender in the nouns borrowed between Jingulu and Mudburra.

TABLE 1 Phonology and semantics of genders in Jingulu (Pensalfini, 2003: 160-164; cf. Chadwick 1975)

\begin{tabular}{|c|c|c|}
\hline Gender & Suffix & Semantics \\
\hline Masculine & $-a$ (sometimes $-j i)$ & $\begin{array}{l}\text { male higher animates, most mammals, raptors, } \\
\text { some fish and insects, flat rounded objects. } \\
\text { Default animate class. }\end{array}$ \\
\hline Feminine & -rni (allomorph -rdi) & $\begin{array}{l}\text { female higher animates, song birds, atypical } \\
\text { animals, some fish and insects, axes. }\end{array}$ \\
\hline Vegetable & $-m i($ allomorph $-b i)$ & $\begin{array}{l}\text { long and thin or pointy items of all sorts } \\
\text { (includes most edible vegetables). }\end{array}$ \\
\hline Neuter: & $-u($ or C-final $)$ & $\begin{array}{l}\text { default inanimate class (includes spherical } \\
\text { edible plants, and body parts that are not pointy } \\
\text { or long and thin). }\end{array}$ \\
\hline
\end{tabular}


The traditional language of the area surrounding Elliott in northern Australia is Jingulu, a Mirndi language (non-Pama-Nyungan), but somewhere between 200 and 500 years ago ${ }^{1}$ the Mudburra settled there and intermarried, introducing Mudburra, a Pama-Nyungan language of the Ngumpin subgroup of Ngumpin-Yapa languages to the area. Jingili ${ }^{2}$ and Mudburra people formed one community for ceremonial and land ownership purposes, sharing a single kinship system (but maintaining distinct kin terms in each language to a large extent). Nowadays people in the area identify as Mudburra, or Mudburra and Jingili, with a very few identifying as Jingili but not Mudburra. The result of this close contact between Jingili and Mudburra people (and to a lesser extent with Warlmanpa and Wambaya people, and to an even lesser extent with Warumungu people) has been a complex ecology of multilingualism and language mixing. Since the colonisation of the area in the late 180os, Kriol and English have been added to the mix and have contributed to the endangerment of Jingulu and Mudburra (see Figure 1). Today there are one or two fluent Jingulu speakers, and Jingulu is not used as a daily language of communication. Mudburra is also severely endangered, and used only between older speakers, and even then infrequently. Despite the dominant presence of Kriol and English in the area, the focus of this paper is on the earlier contact between Jingulu and Mudburra.

Jingulu and Mudburra exhibit high levels of bidirectional noun borrowings. Meakins and Pensalfini (submitted) demonstrated this bidirectional transfer through a comparative database of 871 nouns recorded for both Jingulu (Pensalfini, 2011) and Mudburra (Green et al., 2016; Raymond et al., 2018). They also included corresponding nouns from a number of related and neighbouring languages Wambaya (Mirndi, contiguous with Mudburra and Jingulu) (Nordlinger,

1 This is quite speculative because there are no written records or corresponding events with an archaeological record. Nonetheless we do not believe the contact was much deeper in time because the forms we are discussing are mostly completely corresponding rather than cognates which require sound change explanations. We are also assuming a single contact event, but again this is speculative. In any case, the contact event occurred long after the development of gender suffixes from the encliticisation and reduction of prefixed demonstratives to nominals (Harvey et al., 2006).

2 Jingili is the name of the people and Jingulu is the name of the language. 


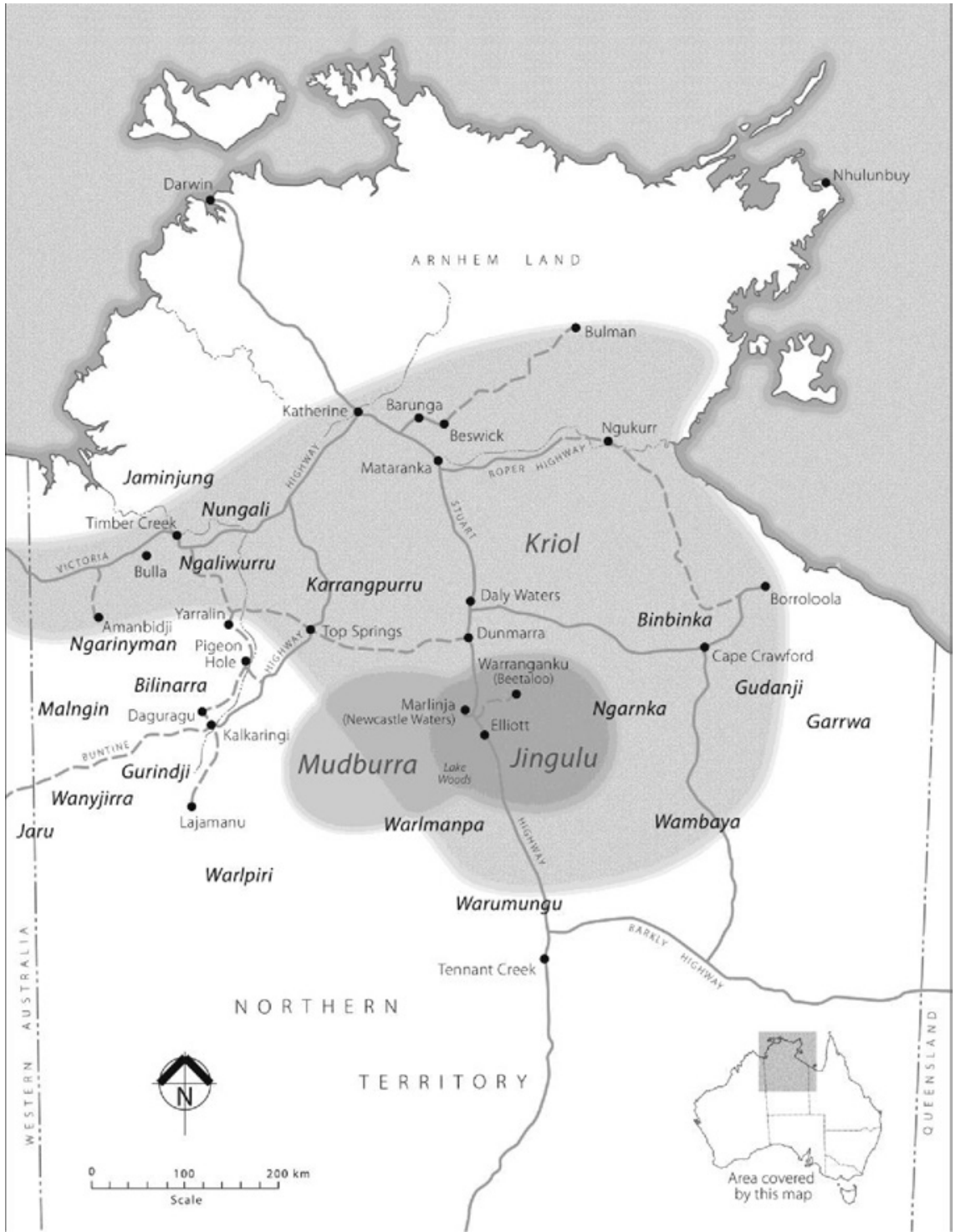

FIGURE 1 Main languages in contact in the Elliott area (Meakins and Pensalfini, 2016: 430)

1998a), Gurindji (Ngumpin, contiguous with Mudburra) (Meakins et al., 2013), Jaminjung (Mirndi, not contiguous with Mudburra or Jingulu) (Jones et al., 2011; Schultze-Berndt and Simard, 2015), Jaru (Ngumpin, not contiguous with Mudburra or Jingulu) (Blythe, 1992; Deegan et al., 2010), Warlmanpa (Yapa, contiguous with Mudburra and Jingulu) (Nash, 2003) and Warumungu 
(Pama-Nyungan isolate, contiguous with Warlmanpa and Wambaya, having had limited contact with Jingulu and none with Mudburra) (Simpson, 2014) (see Figure 1).

The extent and direction of borrowing for nouns was determined by comparing shared forms in Mudburra and Jingulu first with their closest (geographic and phylogenetic) neighbours, Gurindji and Wambaya respectively. Jingulu and Mudburra forms shared with Gurindji were categorised as Mudburra $\rightarrow$ Jingulu; and Jingulu and Mudburra forms shared with Wambaya were categorised as Jingulu $\rightarrow$ Mudburra. The other languages were brought into the comparison when comparisons with Wambaya and Gurindji were not revealing. Meakins and Pensalfini (submitted) found that $65 \%(n=562)$ of nouns are shared between Jingulu and Mudburra, with the direction of borrowing relatively even. $32 \%(\mathrm{n}=181)$ of nouns find their origins in Mudburra and $24.5 \%$ $(n=137)$ of nouns are from Jingulu. ${ }^{3}$ This number (i.e. $\left.65 \%\right)$ is at the higher end of the $40-71 \%$ range estimated by Pensalfini (2001: 393) and higher than the 40-43\% given by Black's (2007: 67) as a revised-down figure. Note that Black did not consider all nouns, but only a sample of basic nouns from a set of 114 vocabulary items recorded by Chadwick (1975) in an attempt to separate established Mudburra borrowings from more recent language obsolescence effects. In this respect, Black's (2007) figure need not be considered inconsistent with those in Pensalfini (2001).

Importantly evidence for the direction of noun borrowings in a subset of 410 nouns was determined only by formal similarity between Mudburra and Jingulu nouns (and their geographic and phylogenetic neighbours) independent of the apparent presence or absence of Jingulu gender suffixes on nouns for a subset of this dataset. This subset of nouns forms the basis of this study, ensuring that our subsequent discussion of the behaviour of gender in noun transfers is free of circularity, i.e. we do not use phonological sequences in a Mudburra noun which are interpretable as gender suffixes as evidence for the direction of transfer from Jingulu into Mudburra. This allows us to independently examine the patterns of gender allocation.

3 This leaves $224(43.5 \%)$ of nouns with an unknown origin according to the methods used by Meakins and Pensalfini (forthcoming) which mostly involved form correspondences with neighbouring languages. We can speculate on the origin of most of these nouns based on gender but did not want to for this paper due to the circularity of argumentation. 
Typical of Pama-Nyungan languages, Mudburra does not have a gender system (or indeed any kind of noun classification system) (discussed further in \$5.2.2). In contrast,Jingulu has a four-way gender system for nouns: masculine, feminine, vegetable and neuter (Chadwick, 1975; Pensalfini, 2003), which is common in non-Pama-Nyungan languages (Harvey and Reid, 1997). Gender of the noun is determined by agreement with modifiers such as adjectives or demonstratives, as shown schematically in (1), where the adjective bardakurr- 'good' shows either masculine, feminine, vegetable and neuter agreement with its noun head (Meakins and Pensalfini, 2016: 426).

$\begin{array}{llllll}\text { MASC } & \text { Bininja } & \text { bardakurr-a } & \text { NEUT } & \text { Darrangku } & \text { bardakurr-u } \\ & \text { man(m) } & \text { good-MASC } & & \text { tree(n) } & \text { good-NEUT } \\ \text { FEM } & \text { Nayurni } & \text { bardakurri-rni } & \text { VEG } & \text { Karnarinymi } & \text { bardakurri-mi } \\ & \text { woman(f) } & \text { good-FEM } & & \text { spear(v) } & \text { good-vEG }\end{array}$

Most gender systems can be classified as either formal (based on the phonological or morphological shape of nouns) or semantic (based on animacy, sex, shape etc of the referent of the noun) (cf. Corbett, 1991), but many gender systems are shaped by both formal and semantic principles. Gender membership in Jingulu is largely predictable from the semantics of the noun, but phonology also plays a role. Each will be discussed in turn.

There are several semantic criteria at play in assigning gender in Jingulu. Masculine includes words for male humans and higher animates (2)(a), feminine includes words for female humans and higher animates $(2)(\mathrm{b})$, vegetable includes many words for edible plants $(2)(\mathrm{c})$, while neuter contains words for many lower animates, and other plants and inanimate objects $(2)(\mathrm{d})$ (Pensalfini, 1999, 2003). Among lower animates, most mammals are masculine, while most birds are feminine. Feminine gender also includes animals that are atypical, such as water creatures that don't swim (much) or insects that sting with their tails. Reptiles and insects are divided between masculine and feminine genders.

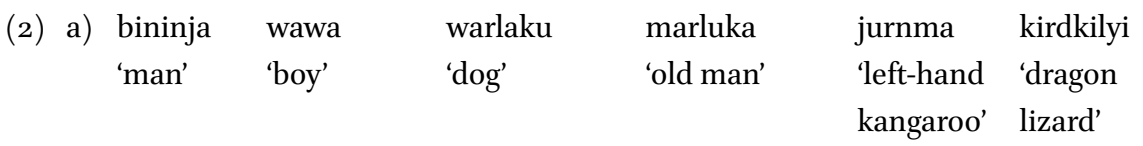



b) nayurni wiwirni warlakurni kirninginjirni jindirrirni 'woman' 'girl' 'female dog' 'emu' 'crab'
c) babirdimi milakurrmi kilibi wardbardbumi 'yam' 'wild potato' 'bush banana' 'bush passionfruit'
d) ngawu kijurlurlu yurrku bikirra kurrubardu 'home' 'stone' 'flower' 'grass' 'boomerang'

Other semantic criteria determining gender assignment include markedness and shape which is not uncommon among semantically-driven gender systems (cf. Corbett, 1991). The vegetable gender in particular appears to be most strongly determined by shape, and is better characterised as the gender of objects whose length significantly exceeds their width (i.e. long thin or pointy objects). Thus, edible vegetables that are not of this shape, such as damang$k a$ 'spherical yam' or kirangkuju 'round melon' are neuter. Conversely, while body parts are typically neuter, ngijinmi 'tail', junkumi 'penis', kilimi 'nose', and mankujbi 'neck', among others, are all vegetable. Also found in the vegetable gender are objects of this shape, such as karnarinymi 'spear', limirnmi 'fishing log' and jaarumi 'shield', and even more abstract versions of this shape such as kingmi 'rainbow' and kaarijbi 'road' (Pensalfini, 2003, p 161). Many inanimate items and body parts are found in the masculine class (3)(a), but relatively few in the feminine (3)(b). The assignment of inanimate objects to masculine gender is often associated with their having a flat and/or rounded shape, but this correlation is less strong than for the assignment of long thing objects to the vegetable class (Pensalfini, 2011).

$\begin{array}{clll}\text { (3) a) } \begin{array}{ll}\text { malamba } \\ \text { 'liver' }\end{array} & \begin{array}{l}\text { biyawuja } \\ \text { 'flat grindstone' }\end{array} & \begin{array}{l}\text { lawunja } \\ \text { 'flat coolamon' 'water' }\end{array} \\ & \begin{array}{ll}\text { jingirdi } \\ \text { 'heart' }\end{array} & \begin{array}{l}\text { dawurdawu/dawurdawurni } \\ \text { 'axe' }\end{array} & \begin{array}{l}\text { ibilkirni } \\ \text { 'rain' }\end{array}\end{array}$

The Jingulu gender system also has a strongly formal component. As can be gleaned from (2)-(3), each of the four genders has a characteristic ending. Masculine words tend to end in - $a$, feminine words in - rni or -rdi, vegetable words in $-m i$ or $-b i$, and neuter words in $-u$ (or a consonant).

Pensalfini (1999) also observed that modifiers can optionally 'disagree' with their head. This type of disagreement, later called 'superclassing' (Corbett, 2012), 
is principled and hierarchical. Masculine-marked modifiers can optionally agree with heads of the feminine gender and neuter-marked modifiers can optionally agree with heads of the vegetable gender, for example in (4) where masculine agreement marking is used on bardakurr- 'good' despite the fact that the head is feminine. Masculine-marked modifiers can also optionally agree with the heads of all four genders, as in (5) (Meakins and Pensalfini, 2016:426-27).

\begin{tabular}{|c|c|c|c|c|c|}
\hline FEM & $\begin{array}{l}\text { Nayurni } \\
\text { woman(f) }\end{array}$ & $\begin{array}{l}\text { bardakurr-a } \\
\text { good-MAsc }\end{array}$ & VEG & $\begin{array}{l}\text { Karnarinymi } \\
\operatorname{spear}(\mathrm{v})\end{array}$ & $\begin{array}{l}\text { bardakurr-u } \\
\text { good-NEUT }\end{array}$ \\
\hline MASC & $\begin{array}{l}\text { Bininja } \\
\operatorname{man}(\mathrm{m})\end{array}$ & $\begin{array}{l}\text { bardakurr-a } \\
\text { good-MASC }\end{array}$ & NEUT & $\begin{array}{l}\text { Darrangku } \\
\text { tree }(n)\end{array}$ & $\begin{array}{l}\text { bardakurr-a } \\
\text { good-MASC }\end{array}$ \\
\hline FEM & $\begin{array}{l}\text { Nayurni } \\
\text { woman(f) }\end{array}$ & $\begin{array}{l}\text { bardakurr-a } \\
\text { good-MASC }\end{array}$ & VEG & $\begin{array}{l}\text { Karnarinymi } \\
\text { spear(v) }\end{array}$ & $\begin{array}{l}\text { bardakurr-a } \\
\text { good-MAsc }\end{array}$ \\
\hline
\end{tabular}

Meakins and Pensalfini (2016:427) claim that three hierarchically ordered generalisations can be made about disagreement patterns in Jingulu:(i) masculine gender is the default for animates, (ii) neuter gender is the default for inanimates, and (iii) masculine agreement is the über-default for all genders. These generalisations are shown schematically in Figure 2.

Of interest for this paper is (i) how Mudburra nouns borrowed into Jingulu were assigned gender, i.e. did the Jingulu principles of phonology, semantics or the default superclasses determine their categorisation (\$5.1); and (ii) whether the extensive borrowing of Jingulu nouns into Mudburra has resulted in the transfer of any aspects of the Jingulu gender system, i.e. the productive use of gender suffixes or agreement ( $\$ 5.2)$. The following section reviews the codeswitching and borrowing literature which has reported on situations where nouns have been transferred between languages where one language marks gender and the other does not (note here we're not concerned with noun

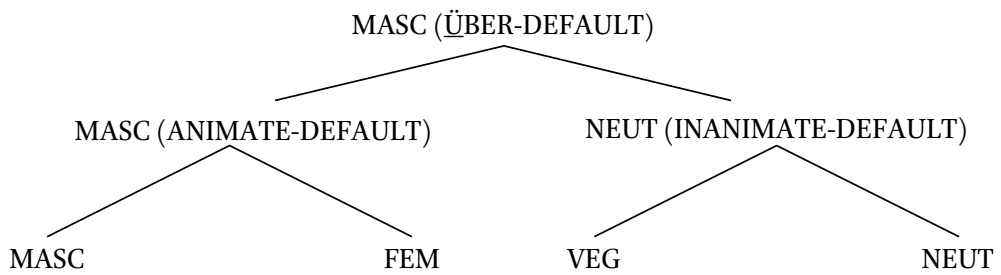

FIGURE 2 Hierarchy of gender disagreement in Jingulu 
transfer between languages which both have gender (e.g. French-Arabic mixed NPs (Bentahila and Davies, 1983)).

\section{$3 \quad$ Gender in Contact Cross-Linguistically}

In language contact settings where noun transfer between languages has occurred, two directions are possible: (i) nouns from a language which has no gender may transfer into a language with a gender system $(\$ 4.1)$, and (ii) nouns from a language with a gender system may transfer into a language without one (§4.2). Of interest in direction (i) are the principles underlying the gender categorisation of loan nouns in the recipient language; and of interest in direction (ii) is the degree to which formal features of a gender system are borrowed, i.e. does gender marking transfer frozen on borrowed nouns, is gender marking productively extended to native stems, and is there evidence for the transfer of (parts of) the agreement system? We examine both scenarios due to the large-scale bidirectional borrowing of nouns that has occurred between Jingulu, which has a gender system, and Mudburra, which does not.

\subsection{Transferring Gender-less Nouns in a Language with Gender}

The first scenario involves the transfer of nouns from a language which does not encode gender into one which does. Many studies in the borrowing and code-switching literature claim that nouns tend to be assigned according to principles underlying the gender assignment system of the recipient language. Other studies show a strong tendency for loanwords to be allocated to a single default gender which overrides native gender assignment principles. In fact, no single principle seems to be at play in most cases, as this section discusses.

Most gender systems can be classified as either formal (based on the phonological or morphological shape of nouns) or semantic (based on animacy, sex, shape etc of the referent of the noun) (cf. Corbett, 1991). Where the recipient language has a semantic system, the assignment of nouns from the source language is often guided by the inherent features of the referent or semantic associations. For example, Tamil has a strict semantic system which divides nouns into masculine, feminine or neuter, with borrowings allocated according to their natural features (sex and animacy) (Asher, 1985: 137). If the recipient language has a formal system of gender assignment, transferred nouns are often categorised according to their phonology or morphology. For example, Swahili has a morphologically-based assignment system (which has some semantic basis) that differentiates 10 genders, and Kibogoya (1995) found that most borrowings from English are categorised according to morphology, 
although semantics also plays a role, for example English animates receive a Class 2 prefix and inanimates are assigned to Class 9 .

Nonetheless other studies find a strong tendency for transferred nouns to be allocated to a default category, suggesting that loanwords are not always treated the same as native nouns. For example, in Spanish-Basque code-switching, where bilingual noun phrases consist of a Basque noun and Spanish articles, bilinguals show a preference for feminine articles (regardless of the gender of the translation equivalent) (Parafita Couto et al., 2015). In Maltese, $86 \%$ of a sample of 94 English nouns were borrowed into the masculine gender, regardless of their phonology and the fact that Maltese has a largely formal system of gender assignment (Stolz, 20og: 335). Similarly, in Spanish-English codeswitching where bilingual noun phrases consist of an English noun and Spanish determiner, bilinguals show a productive preference for masculine articles (regardless of the gender of the translation equivalent) (Deuchar et al., 2014; Jake et al., 2002; Liceras et al., 2008; Poplack et al., 1982). The default preference for masculine articles in Spanish-English code-switching is also supported by recent comprehension studies. Valdés Kroff et al (2017) used an 2-picture visual world eye-tracking study to show that Spanish-English bilinguals who code-switch use feminine, but not masculine gender, as a cue for anticipating nouns in mixed Spanish-English NPs, which they interpret as the result of the extensive use of the masculine article as a default (and therefore unmarked) article in code-switching.

It is not clear what determines default genders. Poplack et al (1982: 21-23) suggests the default gender may be the gender with the largest numbers of nouns in it. This explanation may account for the variable observations of borrowings into Spanish. The Spanish lexicon is roughly split 5o/5o between masculine and feminine nouns (Eddington, 2002), which means that a 'default' strategy could go either way. Valdés Kroff et al (2017: 191) suggest that it may just be the emergence of a community practice which determines whether masculine (e.g. Spanish-English code-switching) or feminine (e.g. Spanish-Basque code-switching) is favoured in switches.

Although many studies attempt to argue for a single principle of gender assignment, either determined by the recipient language system or by default, Poplack et al (1982: $\left.5^{-6}\right)$ note that single factors rarely explain all of the data, suggesting that "[t]he problem with studies which claim predominance of a single factor is the embarrassment of exceptions to be accounted for." For example, even in the cases of loans in Swahili, phonology plays some role. If an English loanword contains an initial segment which is interpretable as a prefix, it is assigned to the appropriate class (Whiteley, 1967, cited in Corbett 1991: 72). Instead Poplack et al consider that a number of factors can be at play simultaneously. 
In contrast with the prevalent approach, i.e. the explanation of gender assignment in terms of one categorical factor (e.g. physiological gender), and the successive explanation of all exceptions by invoking a series of other categorical factors, we have treated all the factors simultaneously, since presumably all are at play at the time of [the] introduction of a given borrowing, particularly in cases of conflict.

POPLACK ET AL., 1982: 25

For example, Poplack et al (1982) show that English nouns in Puerto Rican Spanish and Montreal French by and large were assigned according to the sex of animates and, to a lesser extent, phonology in the case of English loans into Spanish because phonology is a good predictor of gender in Spanish (e.g. $99.87 \%$ of nouns ending with $-o$ are masculine and $96.30 \%$ of nouns ending with $-a$ are feminine (Parafita Couto et al., 2015: 306)). Nonetheless Poplack et al (1982) found that in other cases English nouns were assigned according to the gender of their Spanish or French translation equivalents. Jake et al (2002) made similar findings in their study of 230 mixed NPs from 10 Latin American Spanish-English bilinguals. They found that both phonology and translation equivalence playing a role in the assignment of English nouns.

In §5.1, we examine the gender allocation of Mudburra nouns into Jingulu. Because gender assignment in Jingulu has both phonological and semantic cues, we are interested in the interplay of these two factors. Also of interest is whether a default assignment system, potentially based on gender superclassing already present in the recipient language Jingulu (and therefore unlike the case studies discussed in this section), might influence the categorisation of borrowed Mudburra, i.e. are all Mudburra nouns allocated to masculine gender über-default, or animates to masculine and in animates to neuter?

\subsection{Transferring Gendered Nouns in a Language without Gender}

The other logically possible outcome for two languages in contact where one language has a gender system and the other does not is that (parts of) the gender system may be borrowed. This scenario is claimed to be rare for languages with gender morphology as opposed to gender encoded in free forms such as articles. For example, in a survey of 27 pairs of languages in contact, Matras (2007: 44) finds that "bound case and gender markers remain on the whole among the most stable features in the noun domain, resisting especially direct replication of matter" i.e. borrowing of morphologically-marked gender is unusual. However examples do exist in the broader literature. As this section outlines, three degrees of borrowing can be observed: from the transfer of gender markers fused to the borrowed noun, through to the transfer of structural aspects of the gender system i.e. agreement in various functional 
domains. Reports of the transfer of an agreement system is rare in the literature, as Stolz (2012: 102) observes, "documentation of uncontroversial examples of agreement phenomena is scarce." This is unsurprising given Gardani's (2008) observation that inherent inflection (e.g. number, TAM, gender marking) is more borrowable than contextual inflection (e.g. structural case, person and gender agreement). ${ }^{4}$

Firstly, gender has been observed to enter a language as 'trojan horse structures' (cf. Meakins, 2011: 60) i.e. attached to a loan noun or as a part of the noun phrase e.g. encoded in articles. In these cases, they are morphologically frozen in the recipient language. For example, although there have been claims that Michif (French-Cree mixed language, Canada) has borrowed French determiners (including gender features) (Papen, 2003), others have argued that the liaison processes which affect the final consonant of the determiners in French have fossilised in Michif, thereby precipitating the loss of the gender system while simultaneously creating a plethora of new consonant-initial Frenchorigin words e.g. li zef(Michif) < les oeufs (French) (Bakker, 1997; Rosen, 2007). Slightly more productive are the instances where parts of the Spanish gender system have been borrowed into Ayacucho Quechua (Southern Quechua, Peru) and Ilocano (Austronesian, Philippines) which are languages which lack gender. Spanish gender-marked nouns and agreement on Spanish adjectives are found in these languages, however this agreement system has not extended to native forms (Aikhenvald, 2003: 48, 388).

In other cases, these instantiations of gender have extended to native stems and can therefore be analysed as productive in the recipient language. Note though that in this scenario, the borrowing of a gender system has not occurred due to the lack of agreement. For example, Tadmor (2007, p. 312) observes that Indonesian has borrowed male and female human nouns from Sanskrit and Arabic which are marked for gender with this system becoming productive on some native Indonesian stems. Similarly Risígaro (Arawakan, Brazil) has borrowed two feminine gender suffixes from Bora (Isolate, Brazil) which have been extended to Risígaro stems (Seifart, 2012). Another example comes from Kormakiti (Arabic variety, Cyprus) which has many Greek loanwords. These loanwords retain their some of their morphology, in particular a set of suffixes marking the diminutive, which is further specified for gender and number and which is used productively used on Arabic nouns (e.g. Kossman, 2008).

4 Note that here we are not dealing with cases of borrowed noun classifiers (which do not involve agreement), for example the development of a classifier system in Hup (Nadahup, Amazon) under the influence of Tacano (Tacanoan, Amazon) (Epps, 2006), borrowed Chinese classifiers in Vietnamese (Alves, 2007) or the impressive wholesale transfer of the full paradigm of noun class suffixes from a Bora (Isolate, Brazil) into Risígaro (Arawakan, Brazil) (Seifart, 2012). 
Some claims have also been made for the transfer of parts of the agreement system itself. In Tagalog (Austronesian, Philippines), the Spanish agreement system has extended to some Tagalog nouns. Spanish-derived predicative adjectives in clauses such as The man is a teacher show masculine or feminine agreement in both Spanish loan nouns with human referents and also in some native Tagalog nouns (Schachter and Otanes, 1972: 96-97). Chamorro (Austronesian, Northern Mariana Islands and Guam) has also borrowed large amounts of Spanish vocabulary including nouns, and Stolz (2012) claims that the sizable proportion of Spanish loans which are overtly marked for gender have established a gender agreement system in Chamorro. Warndarang (Gunwinyguan, Australia) has borrowed the non-human gender III, IV and v prefixes (genders I and II are masculine and feminine, respectively and have not been borrowed) from a proto form of Nunggubuyu (Gunwinyguan, Australia). These are clearly borrowed as related languages in the same branch of Gunwinyguan such as Marra do not have a gender system. In the case of Warndarang, the use of these non-human genders was extended to native nouns and included agreement on free pronouns and demonstratives, however Heath (1978: 116) argues that Warndarang "has not taken advantage of all of the functional possibilities for noun-class [gender] prefix systems" which suggests that the system is not entirely productive.

In $§ 5.2$, we examine a set of Jingulu nouns which have been borrowed into Mudburra. Based on the literature, a number of outcomes are possible. Firstly, the Jingulu word may appear in Mudburra, preserving the sequence corresponding to the Jingulu gender suffix as a part of the stem. Secondly, the gender suffixes, particularly the feminine and vegetable gender suffixes (which are the most morphologically transparent and separable of the four gender suffixes) may be productively extended to Mudburra nouns. We are also interested in whether there is any indication that the Jingulu gender agreement system has transferred into Mudburra, which would be evidenced by the use of agreement suffixes on other parts of the Mudburra NP including adjectives and demonstratives. A final possibility not discussed in the literature is that Mudburra would 'strip off' the feminine and vegetable gender suffixes, recognising them as such due to the high degree of bilingualism at the time that the large-scale borrowing of nouns took place.

\section{$4 \quad$ Gender in Mudburra-Jingulu Noun Transfer}

The effect of the gender system of Jingulu on Mudburra noun stems was first noted by Nash (1997: 195) who observed that Jingulu and Mudburra share the word bunaringmi 'wild orange, Capparis umbonata' and hypothesised that it 
was borrowed by Mudburra from Jingulu, with the direction determined by the presence of $-m i$, one of the vegetable suffixes in Jingulu (\$3). In the following sections, we build on Nash's observation about Jingulu-Mudburra noun borrowings and gender. We use the two data subsets - (i) Jingulu $\rightarrow$ Mudburra borrowings and (ii) Mudburra $\rightarrow$ Jingulu borrowings - outlined in (\$2) to examine gender behaviour of noun transfers between the languages. Recall that our criteria for determining the direction of borrowing does not include gender, allowing us to independently examine the gender patterns in both borrowing scenarios.

The data tables throughout $\$ 5$ include the Jingulu and Mudburra forms and their English translation, plus columns headed 'Phonological criteria' and 'Semantic criteria'. These columns comment on whether the noun is typical of the gender class in which it appears (as determined by gender agreement). An entry of "Fine" under 'Phonological criteria' means that the form, as it appears in Jingulu, ends in the characteristic ending for that gender, as set out in §2. If the form is atypical of its class in terms of its phonology, a comment is made to that effect, stating which gender the form resembles. An entry of "Fine" under 'Semantic criteria' indicates that the word's meaning is consistent with the general meaning type associated with the gender, as also set out in $\S$. If the semantics of the word would lead us to expect it to be in a different gender, a comment to this effect is included.

\subsection{Gender Allocation of Mudburra Nouns Borrowed into Jingulu}

In §2, we observed that 410 cases where Jingulu and Mudburra share the noun form can be established based on similarity of form (not including gender endings). 176 (43\%) of these are clear cases of borrowing from Mudburra into Jingulu. In this section, we discuss the allocation of Mudburra nouns to Jingulu genders. To determine factors affecting gender allocation (phonology, semantics, default categorisation), we use the criteria of concord (cf. Pensalfini, 2011) i.e. gender agreement on adjectives or demonstratives $(\S 2)$, rather than endings on noun to establish independent criteria for gender allocation.

\subsubsection{Allocation of Mudburra Nouns to Masculine Gender}

Of the 66 masculine nouns, $97 \%(n=64)$ were unchanged because most nouns already ended in /a/ in Mudburra, which is the most common masculine noun ending in Jingulu ( $\$ 2)$. A small number of others ended in $/ \mathrm{ji} /$, which also looks masculine in Jingulu, as there is a small class of Jingulu masculine nouns which end in this sequence (-ji being an older Mirndi masculine suffix, still used productively in Wambaya). Some examples are given in Table 2. 


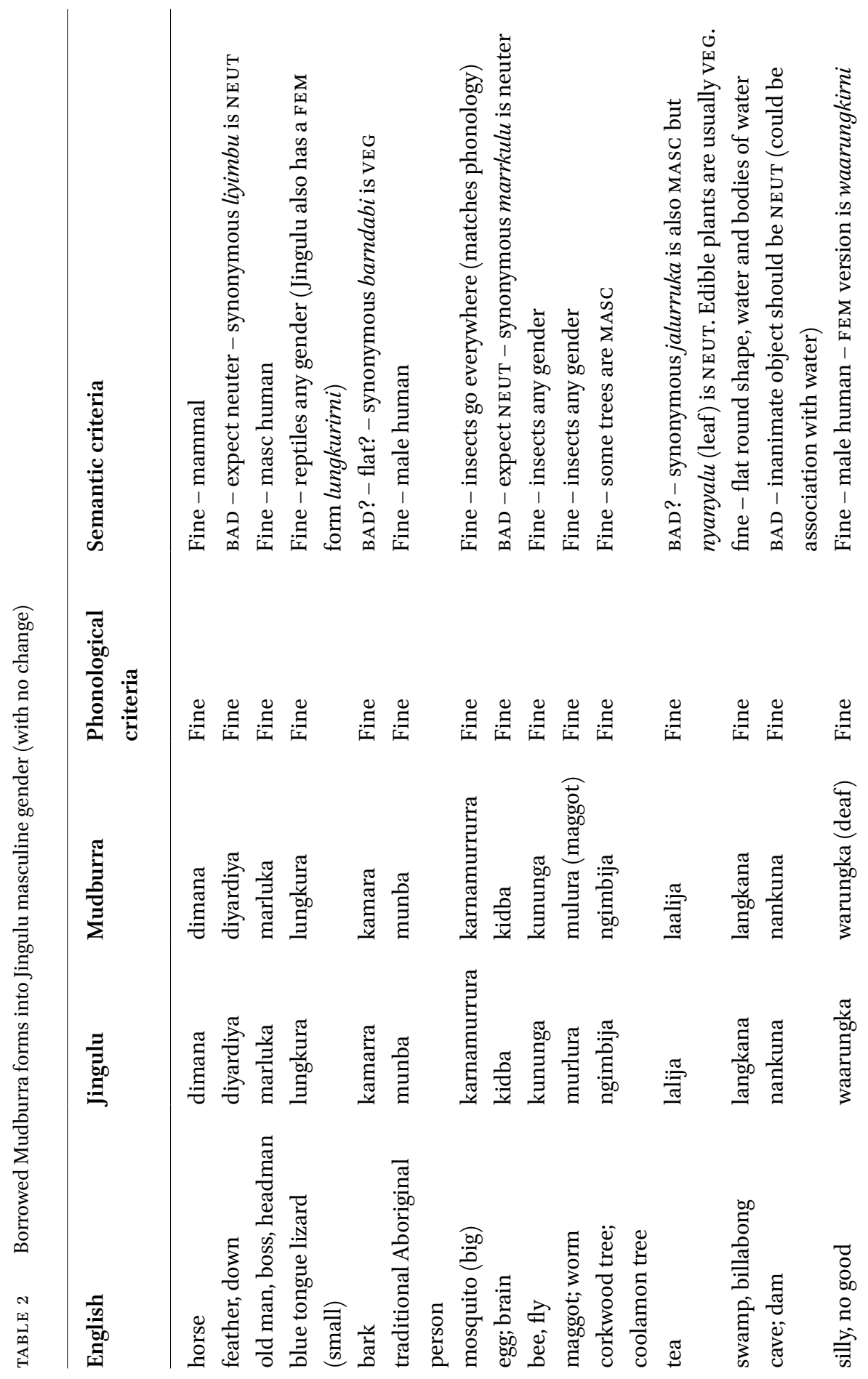




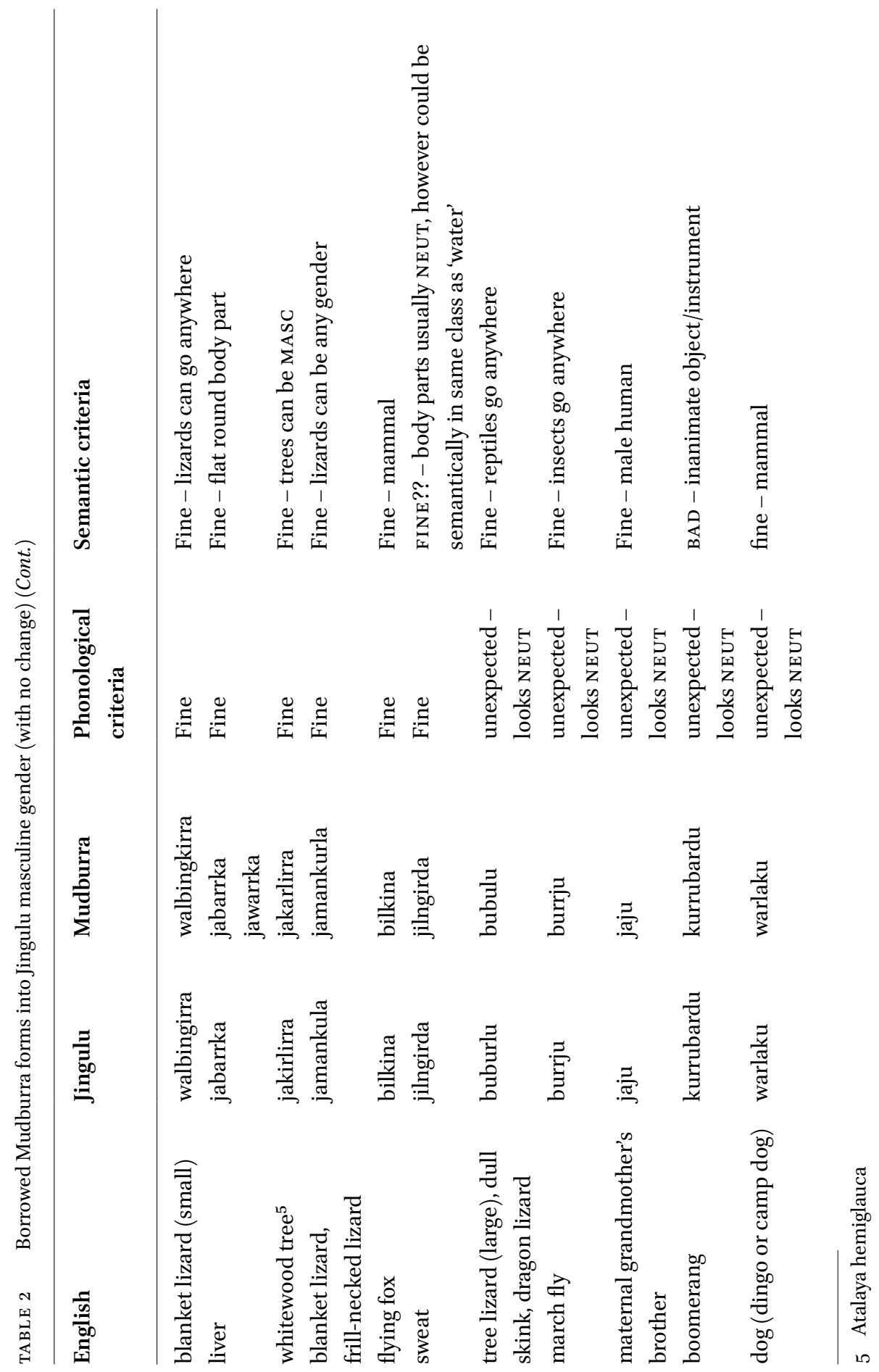



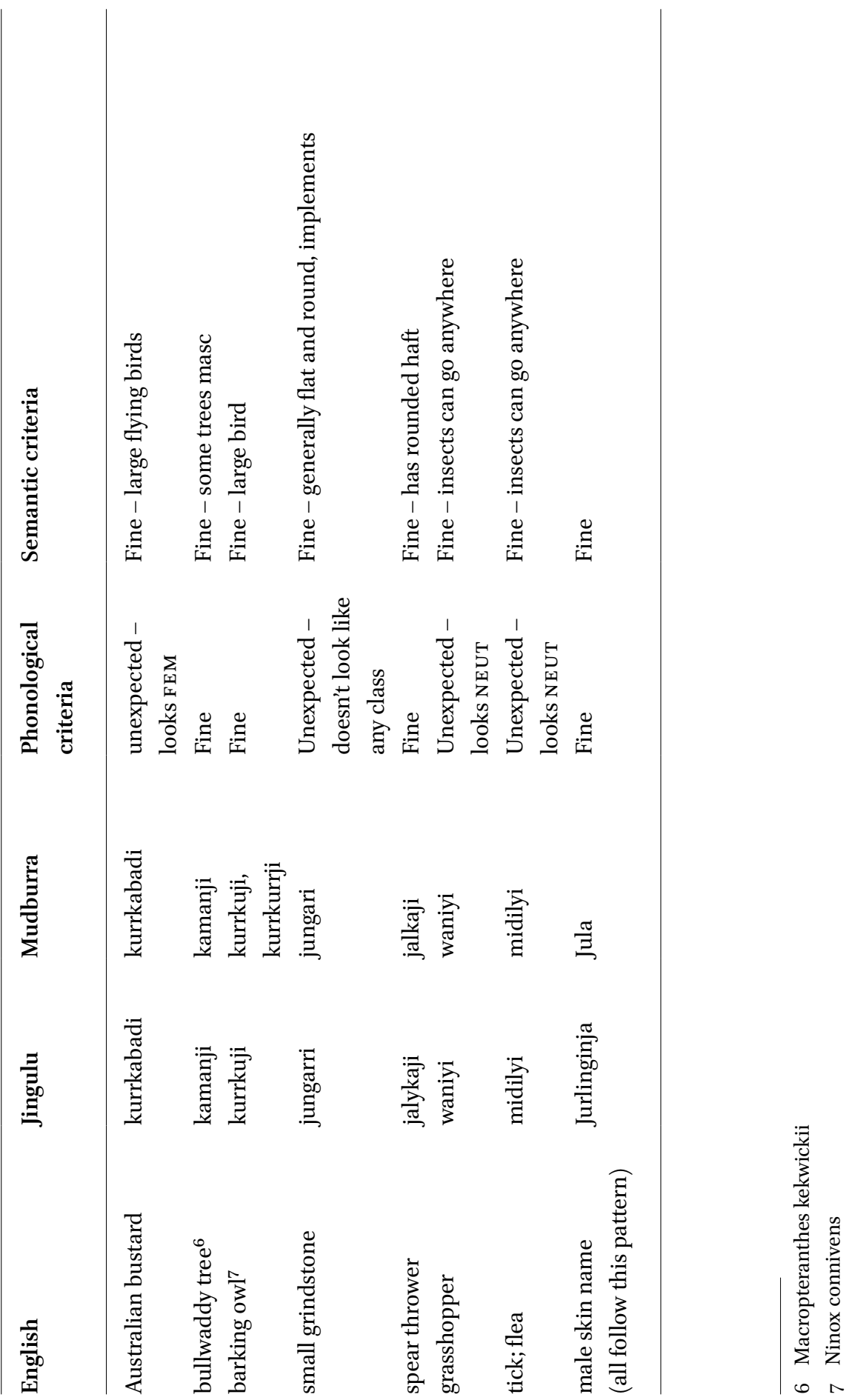
Of the 64 unchanged forms in the masculine gender, $77 \%(n=49)$ have the expected phonology and $86 \%(n=55)$ have the expected semantics. In all, $63 \%$ $(\mathrm{n}=40)$ of unchanged forms have both the expected phonology and semantics. Only one form, kurrubardu 'boomerang', has neither the expected phonology and semantics, although it could be masculine by association with males, as some, but not all, men's weapons are masculine. It should be noted that while the 'expected' phonology for Jingulu masculine nouns is to end in /a/ or, far less commonly, /ji / (which is an older Mirndi masculine morpheme, still found as the usual masculine in Wambaya (Nordlinger, 1998b)), there is quite a bit of variation in the endings of 'native' masculine nouns in Jingulu - far more than for feminine or vegetable, but far less than neuter.

Only two other instances of Mudburra forms borrowed in Jingulu masculine gender are present in the data (Table 3). They show a change of the final Mudburra vowel to /a/ in Jingulu, being the characteristic marker of masculine gender $(\S 2)$. Note that semantically, these nouns are also in the expected masculine gender.

TABLE 3 Borrowed Mudburra forms intoJingulu masculine gender(with some change i.e. $\rightarrow$ a)

\begin{tabular}{lllll}
\hline English & Jingulu & Mudburra & $\begin{array}{l}\text { Phonological } \\
\text { criteria }\end{array}$ & Semantic criteria \\
\hline $\begin{array}{l}\text { grandmother's } \\
\text { brother } \\
\text { hopping mouse }\end{array}$ & ngabuja & ngabuju & Fine & Fine - male human \\
\hline
\end{tabular}

4.1.2 Allocation of Mudburra Nouns to Neuter Gender

Of the 57 cases of neuter gender nouns in Jingulu being borrowed from Mudburra, $84 \%(n=48)$ were unchanged with regards to their endings. Recall from $\S 2$ that neuter is the gender in Jingulu with the most phonological variation in terms of ending. Some examples are in given in Table 4.

Of these 48 neuter forms, $46 \%(n=22)$ have the expected $/ u /$ ending, although the 'expected phonology' count rises to $67 \%(\mathrm{n}=32)$ if we include the forms that don't look like any other gender (remembering that neuter shows the greatest variability in endings in Jingulu). Most of the remainder end in /a/ and therefore 'look masculine' - however Jingulu has a reasonable proportion of /a/-final neuter nouns already. The expected semantics of the neuter gender are found in $96 \%(n=46)$ of these forms. There were no forms that had neither the expected phonology nor semantics, while $60 \%(n=29)$ of forms that had both. 
TABLE 4 Borrowed Mudburra forms into Jingulu neuter gender (with no change)

\begin{tabular}{|c|c|c|c|c|}
\hline English & Jingulu & Mudburra & $\begin{array}{l}\text { Phonological } \\
\text { criteria }\end{array}$ & Semantic Criteria \\
\hline nulla-nulla, club & kuduru & kurduru & Fine & $\begin{array}{l}\text { Fine - spears/shields are } \\
\text { VEG, but other words for } \\
\text { nulla-nullas are also NEUT } \\
\text { so perhaps this a semantic } \\
\text { sub-class }\end{array}$ \\
\hline upper arm, shoulder & murlku & murlku & Fine & Fine - body part \\
\hline tribal scars & barduru & barduru & Fine & Fine - body part \\
\hline house, town & marru & marru & Fine & Fine - body part \\
\hline fingernail & nungkuru & $\begin{array}{l}\text { nungkuru } \\
\text { (hand, fin- } \\
\text { ger, forearm) }\end{array}$ & Fine & Fine - body part \\
\hline wife-relation & karu & karu (child) & Fine & BAD - should be FEM \\
\hline didgeridoo & kinjuwurnu & kinjuwurnu & Fine & $\begin{array}{l}\text { BAD - should be VEG } \\
\text { (long pointy); synonymous } \\
\text { kulungkukbi is VEG }\end{array}$ \\
\hline back, back bone, spine & kumungku & kumungku & Fine & Fine - body part \\
\hline forehead & walu & walu & Fine & Fine - body part \\
\hline wet season & (y)ibu & yibu & Fine & Fine - seasons/times \\
\hline cloud & kulumarra & $\begin{array}{l}\text { kulumarra } \\
\text { (sky) }\end{array}$ & $\begin{array}{l}\text { unexpected - } \\
\text { looks MASC }\end{array}$ & $\begin{array}{l}\text { Fine - synonym mardayi } \\
\text { is NEUT }\end{array}$ \\
\hline ear & langa & langa & $\begin{array}{l}\text { unexpected - } \\
\text { looks MASC }\end{array}$ & Fine - body part \\
\hline fire; firewood & buba & buba & $\begin{array}{l}\text { unexpected - } \\
\text { looks MASC }\end{array}$ & $\begin{array}{l}\text { Fine - fire and related } \\
\text { things }\end{array}$ \\
\hline sore & marndara & marndara & $\begin{array}{l}\text { unexpected - } \\
\text { looks MASC }\end{array}$ & Fine - body part \\
\hline $\begin{array}{l}\text { ochre (red), } \\
\text { red paint }\end{array}$ & kalnga & kalnga & $\begin{array}{l}\text { unexpected - } \\
\text { looks MASC }\end{array}$ & Fine - object \\
\hline cheek, jaw & kangarnda & kangarnda & $\begin{array}{l}\text { unexpected - } \\
\text { looks MASC }\end{array}$ & Fine - body part (gen) \\
\hline charcoal & linyarda & linyarda & $\begin{array}{l}\text { unexpected - } \\
\text { looks MASC }\end{array}$ & fine - fire and related things \\
\hline windbreak & narranjana & narranjarna & $\begin{array}{l}\text { unexpected - } \\
\text { looks MASC }\end{array}$ & Fine - object \\
\hline clothes & (w)abaaba & wabawaba & $\begin{array}{l}\text { unexpected - } \\
\text { looks MASC }\end{array}$ & Fine - object \\
\hline
\end{tabular}


TABLE 4 Borrowed Mudburra forms into Jingulu neuter gender (with no change) (Cont.)

\begin{tabular}{|c|c|c|c|c|}
\hline English & Jingulu & Mudburra & $\begin{array}{l}\text { Phonological } \\
\text { criteria }\end{array}$ & Semantic Criteria \\
\hline grass (any) & yuka & yuka, bikirra & $\begin{array}{l}\text { unexpected - } \\
\text { looks MASC }\end{array}$ & Fine - inedible plant \\
\hline $\begin{array}{l}\text { open space, } \\
\text { clearing, outdoors }\end{array}$ & bakara & bakara & $\begin{array}{l}\text { unexpected - } \\
\text { looks MASC }\end{array}$ & Fine - landscape \\
\hline tongue & jalanya & jalanya & $\begin{array}{l}\text { unexpected - } \\
\text { looks MASC }\end{array}$ & Fine - body part \\
\hline ashes & buna & buna & $\begin{array}{l}\text { unexpected - } \\
\text { looks MASC }\end{array}$ & $\begin{array}{l}\text { Fine - fire and related } \\
\text { things }\end{array}$ \\
\hline rib, side & janyburra & janyburra & $\begin{array}{l}\text { unexpected - } \\
\text { looks MASC }\end{array}$ & Fine - body part \\
\hline $\begin{array}{l}\text { wax (plant or } \\
\text { ear wax) }\end{array}$ & jikala & jikala & $\begin{array}{l}\text { unexpected - } \\
\text { looks MASC }\end{array}$ & $\begin{array}{l}\text { Fine - body/plant part } \\
\text { (gen) }\end{array}$ \\
\hline $\begin{array}{l}\text { initiation songs } \\
\text { (women's), women's } \\
\text { dance (part of boy's } \\
\text { initiation) }\end{array}$ & bandimi & bandimi & $\begin{array}{l}\text { unexpected - } \\
\text { looks VEG }\end{array}$ & Fine - ceremony \\
\hline $\begin{array}{l}\text { woomera, spear } \\
\text { thrower }\end{array}$ & warlmayi & warlmayi & $\begin{array}{l}\text { ?? - doesn't } \\
\text { look like any } \\
\text { gender }\end{array}$ & $\begin{array}{l}\text { Fine - not long and thin, } \\
\text { has flat handle }\end{array}$ \\
\hline ironwood $^{8}$ & karndi & karndi (tree) & $\begin{array}{l}\text { ?? - doesn't } \\
\text { look like any } \\
\text { gender }\end{array}$ & Fine - trees \\
\hline chest & mangarli & mangarli & $\begin{array}{l}\text { ?? - doesn't } \\
\text { look like any } \\
\text { gender }\end{array}$ & Fine - body part \\
\hline cloud & madayi & mardayi & $\begin{array}{l}\text { ?? - doesn't } \\
\text { look like any } \\
\text { gender }\end{array}$ & Fine - weather \\
\hline shade & ngandayi & $\begin{array}{l}\text { ngandayi, } \\
\text { ngandawi }\end{array}$ & $\begin{array}{l}\text { Fine (neut } \\
\text { residue) }\end{array}$ & Fine - landscape \\
\hline fight & (y)ingiyingi & $\begin{array}{l}\text { yingiyingi (cv. } \\
\text { provoke) }\end{array}$ & $\begin{array}{l}\text { ?? - doesn't } \\
\text { look like any } \\
\text { gender }\end{array}$ & $\begin{array}{l}\text { Fine - abstract action (same } \\
\text { as synonymous bunbaku) }\end{array}$ \\
\hline
\end{tabular}

8 Eythrophleum chlorostachyum. 
Examples of Mudburra forms borrowed in Jingulu neuter gender where the form has changed also exist, They typically involve replacing the final vowel of the Mudburra word with $/ \mathrm{u} /$. There were nine such examples given in Table 5 :

While adjectival nouns almost always take $-u$ when agreeing with a neuter gender referent, substantives in the neuter gender can end in any segment, although the great majority do end in $/ \mathrm{u} /$, with most of the rest evenly divided between $/ \mathrm{a} /, / \mathrm{i} /$, and permissible word-final consonants. This would also explain why some of the changes are not to the characteristic $/ \mathrm{u} /$. The only truly unexpected change in form is of nyili to nyila ('fin of fish'). The form for 'chewing mix' is derived by adding the comitative suffix -ngkujk- to the Mudburra form prior to suffixing the neuter gender marker $-u$. The changes to the form of the word for 'short ribs' are unexplained. Once again, all of these words would be expected to fall into the neuter gender on the basis of their semantics.

TABLE 5 Borrowed Mudburra forms into Jingulu neuter gender (with some change i.e. $\rightarrow$ u)

\begin{tabular}{|c|c|c|c|c|}
\hline English & Jingulu & Mudburra & $\begin{array}{l}\text { Phonological } \\
\text { Criteria }\end{array}$ & $\begin{array}{l}\text { Semantic } \\
\text { criteria }\end{array}$ \\
\hline $\begin{array}{l}\text { hot weather } \\
\text { before wet }\end{array}$ & barungku & barungka & Fine & $\begin{array}{l}\text { Fine - seasons and } \\
\text { times of day }\end{array}$ \\
\hline eye & ngabanju & ngabanyji & Fine & Fine - body part \\
\hline fin of fish & nyila & nyili (spike of fish) & $\begin{array}{l}\text { BAD - looks } \\
\text { MASC }\end{array}$ & Fine - body part \\
\hline $\begin{array}{l}\text { hook } \\
\text { boomerang } \\
\text { ('Number 7') }\end{array}$ & warridirli & $\begin{array}{l}\text { warrirdila, } \\
\text { wardadilya }\end{array}$ & $\begin{array}{l}\text { BAD - doesn't } \\
\text { look like any } \\
\text { gender }\end{array}$ & $\begin{array}{l}\text { Fine - implement/ } \\
\text { weapon }\end{array}$ \\
\hline mist, fog & jungunaku & $\begin{array}{l}\text { jungurn (cv. smoke/ } \\
\text { dust rising) }\end{array}$ & Fine & Fine - weather \\
\hline $\begin{array}{l}\text { tight (fist), tied } \\
\text { (shoelaces etc.) }\end{array}$ & manyburrili & $\begin{array}{l}\text { manburr (cv. close } \\
\text { legs or mouth) }\end{array}$ & $\begin{array}{l}\text { BAD - doesn't } \\
\text { look like any } \\
\text { gender }\end{array}$ & $\begin{array}{l}\text { Fine - property } \\
\text { of inanimate }\end{array}$ \\
\hline $\begin{array}{l}\text { chewing mix } \\
\text { (tobacco with } \\
\text { ashes) }\end{array}$ & bunangkujku & buna (ashes) & Fine & Fine - object \\
\hline $\begin{array}{l}\text { red, light brown, } \\
\text { red sand, }\end{array}$ & bilyingbiyaku & bilyingbilyinga & Fine & $\begin{array}{l}\text { Fine - property } \\
\text { of inanimate }\end{array}$ \\
\hline short ribs & jimbangu & $\begin{array}{l}\text { jiminkina } \\
\text { (rib bone) }\end{array}$ & Fine & Fine - body part \\
\hline
\end{tabular}


4.1.3 Allocation of Mudburra Nouns to Feminine Gender

Of the 25 nouns in feminine gender that were borrowed from Mudburra, only $20 \%(n=5)$ were unchanged from their Mudburra form, which are given in Table 6.

Of these five forms, only $40 \%(\mathrm{n}=2)$ have the expected feminine ending -rni/-rdi, while $60 \%(n=3)$ have atypical endings. $80 \%(n=4)$ have the expected semantics (see Meakins and Pensalfini (submitted) for a discussion about bird names). $40 \%(n=2)$ have both the expected phonology and the expected semantics. The one outstanding form, kabila 'digging stick', does not look like a feminine noun. As noted in Table 6, there are two other terms for 'digging stick' in Jingulu, one of which is masculine and the other also feminine. While the shape of the item would suggest it should be vegetable gender, it could be that it is feminine gender by association with women, who typically use these to dig tubers.

In other cases, Mudburra forms borrowed in Jingulu feminine gender have changed form. Jingulu adds the feminine suffix - $(r) n i$ (or more accurately $-i(r)$ $n i$, replacing any final vowel), and this triggers regressive vowel harmony in the stem, changing adjacent instances of $/ \mathrm{a} /$ to $/ \mathrm{i} /$. The process spreads leftwards, and is stopped by the presence of a vowel which is already high $(/ \mathrm{i} /$ or $/ \mathrm{u} /)$

TABLE 6 Borrowed Mudburra forms into Jingulu feminine gender (with no change)

\begin{tabular}{|c|c|c|c|c|}
\hline English & Jingulu & Mudburra & $\begin{array}{l}\text { Phonological } \\
\text { criteria }\end{array}$ & Semantic criteria \\
\hline $\begin{array}{l}\text { diamond dove, } \\
\text { peaceful dove }\end{array}$ & kularnkurrurdi & $\begin{array}{l}\text { kulankurridi } \\
\text { kulankurru }\end{array}$ & Fine & Fine - smaller birds \\
\hline $\begin{array}{l}\text { sulphur crested } \\
\text { cockatoo }\end{array}$ & bangarra & banngarra & $\begin{array}{l}\text { unexpected - } \\
\text { looks MASC }\end{array}$ & Fine - cockatoos \\
\hline mistletoe bird & jindiminya & jindiminya & $\begin{array}{l}\text { unexpected - } \\
\text { looks MASC }\end{array}$ & fine - smaller birds \\
\hline $\begin{array}{l}\text { storm bird, } \\
\text { rain-bird }\end{array}$ & kurrkurrmirni & kurrkurrmini & Fine & fine - smaller birds \\
\hline $\begin{array}{l}\text { digging stick, } \\
\text { yam stick }\end{array}$ & kiyali & kiyarri & $\begin{array}{l}\text { Unexpected - } \\
\text { doesn't look } \\
\text { like any class }\end{array}$ & $\begin{array}{l}\text { questionable - should be } \\
\text { VEG, or possibly MASC } \\
\text { (synonymous kabila is } \\
\text { MASC, but synonymous } \\
\text { makalyani is also } \\
\text { FEM - association with } \\
\text { women?) }\end{array}$ \\
\hline
\end{tabular}


(Pensalfini, 2002). There were 20 such forms in the database, outnumbering unchanged feminine borrowed forms by a ratio of 4:1. Some examples are given in Table 7.

With the exception of the two words for 'bilby', gender membership for these words is predictable from their semantics. The Jingulu female subsection terms all end in the sequence /nginju/, which at first looks odd, however, this represents an older Mirndi pattern which, as discussed in Meakins and Pensalfini (submitted), affects subsection terms.

TABLE 7 Borrowed Mudburra forms into Jingulu feminine gender (with some change i.e. $\rightarrow(r)$ ni)

\begin{tabular}{|c|c|c|c|c|}
\hline English & Jingulu & Mudburra & $\begin{array}{l}\text { Phonological } \\
\text { criteria }\end{array}$ & Semantic criteria \\
\hline butterfly, moth & marlimarlirni & marlimarli & Fine & $\begin{array}{l}\text { Fine }- \text { insects can be } \\
\text { any gender }\end{array}$ \\
\hline bilby & yalbawurrini $^{9}$ & jalbawurru & Fine & $\begin{array}{l}\text { Unexpected - } \\
\text { mammals are MASC }\end{array}$ \\
\hline bilby & yarningkirni & yarningki & Fine & $\begin{array}{l}\text { Unexpected - } \\
\text { mammals are MASC }\end{array}$ \\
\hline $\begin{array}{l}\text { grandmother } \\
\text { (paternal) }\end{array}$ & ngabujirni & ngabuju & Fine & Fine - female human \\
\hline scorpion & mundarlirni & mundarla & Fine & $\begin{array}{l}\text { Fine - stinging } \\
\text { insects }\end{array}$ \\
\hline tomahawk & mayingkirni & mayingka & Fine & $\begin{array}{l}\text { Fine }- \text { all axes are } \\
\text { FEM }\end{array}$ \\
\hline $\begin{array}{l}\text { granddaughter } \\
\text { (maternal) }\end{array}$ & kaminjirrirni & kaminyjarra & Fine & Fine - female human \\
\hline $\begin{array}{l}\text { blue tongue } \\
\text { lizard }\end{array}$ & $\begin{array}{l}\text { lungkurirni } \\
\text { (female), } \\
\text { lungkura (male) }\end{array}$ & lungkura & Fine & $\begin{array}{l}\text { Fine - lizards can } \\
\text { be any gender - some } \\
\text { reptiles vary gender } \\
\text { depending on } \\
\text { biological sex }\end{array}$ \\
\hline $\begin{array}{l}\text { tawny frog- } \\
\text { mouth, mopoke }\end{array}$ & jurdiyini & jurdiyina & Fine & Fine - bird \\
\hline
\end{tabular}

9 Note this is also a case of initial lenition. Other examples exist in the database such as the word for 'corkwood tree', which is kulunjurru in Jingulu and wulunjurru in Mudburra. For further discussion see Meakins and Pensalfini (submitted). 
TABLE 7 Borrowed Mudburra forms into Jingulu feminine gender (with some change i.e. $\rightarrow$ (r)ni) (Cont.)

\begin{tabular}{|c|c|c|c|c|}
\hline English & Jingulu & Mudburra & $\begin{array}{l}\text { Phonological } \\
\text { criteria }\end{array}$ & Semantic criteria \\
\hline girl & $\begin{array}{l}(\mathrm{w}) \\
\text { amarlakardini }\end{array}$ & wamarla & Fine & Fine - female human \\
\hline $\begin{array}{l}\text { bat (small), } \\
\text { flying fox (small) }\end{array}$ & ngaliminymirni & $\begin{array}{l}\text { ngarlamany- } \\
\text { manya, } \\
\text { ngarlaminymina }\end{array}$ & Fine & $\begin{array}{l}\text { Fine - atypical } \\
\text { animal }\end{array}$ \\
\hline $\begin{array}{l}\text { female skin } \\
\text { name, same sub- } \\
\text { section as male } \\
\text { Jabijinnginja } \\
\text { (all follow this } \\
\text { pattern) }\end{array}$ & Nabijinnginju & Nambijinba & $\begin{array}{l}\text { BAD - looks } \\
\text { neuter, but see } \\
\text { below }\end{array}$ & Fine - female human \\
\hline $\begin{array}{l}\text { emu; Dromaius } \\
\text { novaehollandiae }\end{array}$ & kirninginjirni & karnanganja & Fine & Fine - atypical animal \\
\hline
\end{tabular}

4.1.4 Allocation of Mudburra Nouns to Vegetable Gender

Finally, of the 19 Mudburra nouns borrowed into vegetable gender in Jingulu, $21 \%(n=4)$ were unchanged, as shown in Table 8.

In all but one of these cases, ngurrmana 'blanket', the Mudburra form already ended in a sequence i.e. - $m i$ or $-b i$ which Jingulu would recognise as a characteristic ending for the vegetable gender $(\$ 2)$. Three of the four forms have the expected semantics, with the fourth form being the name of a plant part. Half of them had both the expected semantics and phonology.

Other cases where Mudburra forms are borrowed in Jingulu vegetable gender all involve adding -mi (or its allomorph - bi), Jingulu's characteristic vegetable gender ending, to the Mudburra word $(\$ 2)$. If the word is vowel-final, the final vowel is usually replaced with /i/. This ending, like the feminine - $(r) n i$, triggers regressive vowel harmony (Pensalfini 2002). There were 15 such forms in the database, outnumbering unchanged vegetable gender borrowings by almost 3:1. See Table 9 for some of the forms:

The phonological changes are entirely predictable, and most of these nouns fit the semantics of the vegetable gender class. 
TABLE 8 Borrowed Mudburra forms into Jingulu vegetable gender (with no change)

\begin{tabular}{|c|c|c|c|c|}
\hline English & Jingulu & Mudburra & $\begin{array}{l}\text { Phonological } \\
\text { criteria }\end{array}$ & Semantic criteria \\
\hline yellow-jacket tree ${ }^{10}$ & kambulumi & kambululmi & Fine & $\begin{array}{l}\text { Fine - edible gum } \\
\text { on tree }\end{array}$ \\
\hline bark & barndabi & barndabi & Fine & $\begin{array}{l}\text { unexpected - tree } \\
\text { parts usually neuter }\end{array}$ \\
\hline bush banana & kilibi & kilibi & Fine & fine \\
\hline $\begin{array}{l}\text { blanket, traditional } \\
\text { initiation headwear, } \\
\text { string, radio, wireless }\end{array}$ & ngurrmana & $\begin{array}{l}\text { ngurrmana } \\
\text { (string) } \\
\text { barlkina } \\
\text { (blanket) }\end{array}$ & $\begin{array}{l}\text { Unexpected - } \\
\text { looks MASC }\end{array}$ & $\begin{array}{l}\text { Fine - extension of } \\
\text { 'string' meaning }\end{array}$ \\
\hline
\end{tabular}

TABLE 9 Borrowed Mudburra forms into Jingulu vegetable gender (with some change i.e. $\rightarrow \mathrm{mi} / \mathrm{bi}$ )

English Jingulu Mudburra $\begin{aligned} & \text { Phonological Semantic criteria } \\ & \text { criteria }\end{aligned}$

\begin{tabular}{|c|c|c|c|c|}
\hline $\begin{array}{l}\text { wild onion } \\
\text { tail }\end{array}$ & $\begin{array}{l}\text { kinyuwurrumi } \\
\text { nyinjimi }\end{array}$ & $\begin{array}{l}\text { kinyuwurra } \\
\text { nyinyji (lower } \\
\text { back) }\end{array}$ & $\begin{array}{l}\text { Fine } \\
\text { Fine }\end{array}$ & $\begin{array}{l}\text { Fine - edible plants } \\
\text { Fine - long thin body } \\
\text { parts }\end{array}$ \\
\hline $\begin{array}{l}\text { soap tree } \\
\text { navel, umbilical } \\
\text { cord }\end{array}$ & $\begin{array}{l}\text { bilangbilangmi } \\
\text { majulujulubi }\end{array}$ & $\begin{array}{l}\text { bulangbulang } \\
\text { majula } \\
\text { (stomach) }\end{array}$ & $\begin{array}{l}\text { Fine } \\
\text { Fine }\end{array}$ & $\begin{array}{l}\text { Fine - plants } \\
\text { Fine - umbilical cord, } \\
\text { like other ropes etc are } \\
\text { veg (long and thin), } \\
\text { navel is extension. }\end{array}$ \\
\hline spear & karnarrinymi & karna & Fine & Fine - spears are VEG \\
\hline ceremonial ring & ngirrinyinmi & ngarranyana & Fine & $\begin{array}{l}\text { Bad - ceremonial words } \\
\text { are usually neuter. } \\
\text { Shape doesn't seem } \\
\text { right either. }\end{array}$ \\
\hline hip, rump & mirimi & maru (hip) & Fine & $\begin{array}{l}\text { Bad - body parts are } \\
\text { neuter, shape doesn't } \\
\text { seem right. }\end{array}$ \\
\hline
\end{tabular}

10 Terminalia canescens 
TABLE 9 Borrowed Mudburra forms into Jingulu vegetable gender (with some change i.e. $\rightarrow \mathrm{mi} / \mathrm{bi}$ ) (Cont.)

\begin{tabular}{|c|c|c|c|c|}
\hline English & Jingulu & Mudburra & $\begin{array}{l}\text { Phonological } \\
\text { criteria }\end{array}$ & Semantic criteria \\
\hline knee; elbow & mujumi & $\begin{array}{l}\text { munjuna } \\
\text { (elbow); } \\
\text { dingari (knee) }\end{array}$ & Fine & $\begin{array}{l}\text { Fine - pointed body } \\
\text { part }\end{array}$ \\
\hline $\begin{array}{l}\text { grass with } \\
\text { prickly seeds }\end{array}$ & burrurrumi & bururru & Fine & Fine - pointy 'fruit' \\
\hline shield & kurdujumi & $\begin{array}{l}\text { kurduju, } \\
\text { kuwarri, mirda }\end{array}$ & Fine & Fine - long thin object \\
\hline $\begin{array}{l}\text { fire-stick } \\
\text { tree; Premna } \\
\text { acuminata }\end{array}$ & kungkulimi & kungkarla & Fine & $\begin{array}{l}\text { Fine - long pointed } \\
\text { shape }\end{array}$ \\
\hline back of neck & jikidikidibi & jikirdikirdi & Fine & $\begin{array}{l}\text { Fine - long thin body } \\
\text { part }\end{array}$ \\
\hline $\begin{array}{l}\text { wild curry } \\
\text { kurrajong; } \\
\text { Brachychiton } \\
\text { multicaulis }\end{array}$ & miyikimi & miyaka & Fine & Fine - edible vegetable \\
\hline fishing log & limirnmi & liminmi & Fine & Fine - long thin object \\
\hline
\end{tabular}

4.1.5 Summary

What determines which gender Mudburra nouns were allocated to when they were borrowed into Jingulu? The data shows that no single factor accounts for all cases, which is in line with Poplack et al's (1982) observation about the competing and simultaneous influences of factors in gender systems. Firstly, we find that the über-superclass of masculine does not play an absolute default role in gender allocation, but rather the masculine and neuter genders, which are the default Jingulu animate and inanimate superclasses respectively, are most salient. Most commonly, Mudburra nouns are allocated masculine gender $(40 \%, n=66)$ or neuter gender $(34 \%, n=57)$. In comparison, only a small number of Mudburra nouns were allocated to the feminine $(15 \%, n=25)$ and vegetable gender $(11 \%, n=19)$ which are considered specialised classes within the superclassing system. Nouns which are borrowed into the latter two specialised classes almost always have their endings altered to fit the characteristic endings of these classes, unless they already match them in their Mudburra form. 
In general, $27 \%(n=45)$ of Mudburra loans show a change in their ending in ways which relate to their gender allocation. ${ }^{11} 4.5 \%(\mathrm{n}=2)$ are masculine, $20 \%$ $(n=9)$ are neuter, $44.5 \%(n=20)$ are feminine, and $31 \%(n=14)$ are vegetable. In contrast, nouns which are borrowed into the masculine and neuter genders are most likely to remain unaltered in terms of their endings, largely because they match the characteristic phonology of these classes. $73 \%$ (n=122) of the 167 loans from Mudburra into Jingulu show no change to the ending of the noun. All of this would suggest that phonology is a strong determinant of gender allocation, however we find that the semantic criteria plays a significant role. Of the 122 Mudburra nouns which don't change when they are borrowed into Jingulu, $88 \%(\mathrm{n}=107)$ have the expected semantics, $71 \%(\mathrm{n}=87)$ have the expected phonology (and 60\% ( $\mathrm{n}=73)$ have both the expected phonology and semantics).

\subsection{Gender Suffixes on Jingulu Nouns Borrowed into Mudburra}

In this section we examine what happens to the gender endings on Jingulu nouns when they are borrowed into Mudburra, a language with no grammatical gender. $22.5 \%(\mathrm{n}=92)$ of all 410 shared show this direction of borrowing.

4.2.1 The Productivity of Gender on Borrowed Jingulu Nouns Stems In $85 \%(n=78)$ of cases where a Jingulu noun is borrowed into Mudburra, the gender marker is borrowed as part of the noun, as shown in Table 10.

Of these unchanged Jingulu-origin nouns, $46 \%(n=36)$ are masculine in Jingulu, 19 of them ending with the characteristic masculine $-a$, and eight with the older Mirndi masculine $-j i$. The remaining eight end in $/ \mathrm{i} /$ but not as part of a recognisable gender ending. $27 \%(\mathrm{n}=21)$ of the unchanged words are neuter in Jingulu, eight of which end with the characteristic neuter $-u, 11$ end in /a/, and two end in /i/, but not as part of a recognisable gender ending (none are consonant final). $15 \%(\mathrm{n}=12)$ are feminine in Jingulu, 10 of which end with the characteristic feminine -rni, one ending in /i/ but not as part of a recognisable gender suffix, and one ending in $/ \mathrm{u} /$. Finally $12 \%(\mathrm{n}=9)$ are vegetable in Jingulu, all of which end with the characteristic vegetable suffix -mi.

Despite the majority of Jingulu forms remaining unchanged in the process of borrowing into Mudburra, we found 14 cases $(15 \%)$ where there are changes to the end of the word from Jingulu to Mudburra. These are organised and discussed by the nature of the change in Table 11-Table 15.

11 Note that there were some other changes in a handful of stems, but we are not interested in such matters as lenition at the beginning or stem-internally, minor changes to vowels stem-internally (other than those conditioned by feminine and vegetable suffixes), or the addition of derivational morphology in Jingulu. 
TABLE 10 Jingulu nouns borrowed into Mudburra with no changes

\begin{tabular}{|c|c|c|c|}
\hline English & Jingulu & Jingulu Gender & Mudburra \\
\hline $\begin{array}{l}\text { fingernail, toenail, } \\
\text { claw, talon }\end{array}$ & milinji & MASC & milinji \\
\hline hill kangaroo & (w)ankurra & MASC & wankurra \\
\hline ta-ta lizard & kaburi & MASC & kaburi \\
\hline jabiru & karrinji & MASC & karrinji \\
\hline spider & karruji & MASC & karruji \\
\hline baby (human) & manjala & MASC & manjala \\
\hline $\begin{array}{l}\text { woomera, } \\
\text { spearthrower }\end{array}$ & ngarlika & MASC & ngarlika \\
\hline red-legged stilt & nginginji & MASC & nginginji \\
\hline left-handed (person) & (w)akunya & MASC & wakunya \\
\hline $\begin{array}{l}\text { spinifex grass, } \\
\text { spinifex wax }\end{array}$ & kirnima & MASC & $\begin{array}{l}\text { kinima (spinifex } \\
\text { wax) }\end{array}$ \\
\hline freshwater mussel & marlangayi & MASC & marlangayi (mussel) \\
\hline hungry & balika & MASC & balika \\
\hline ochre (yellow) & dankurra & MASC & dankurra \\
\hline ghost gum & darralyaka & MASC & darralyaka \\
\hline star & jirnkiji & MASC & jinkiji \\
\hline $\begin{array}{l}\text { western brown } \\
\text { snake }\end{array}$ & ngayiliji & MASC & ngayiliji \\
\hline $\begin{array}{l}\text { whirlwind, } \\
\text { willy-willy }\end{array}$ & mayamba & MASC & mayamba \\
\hline bone & kardakarda & NEUT & kardakarda \\
\hline muscle, flesh, beef & kanyburru & NEUT & kanyburru \\
\hline armpit & wanjku & NEUT & wanyku \\
\hline headband & bakuri & NEUT & $\begin{array}{l}\text { bakuri (women's, } \\
\text { ceremonial) }\end{array}$ \\
\hline $\begin{array}{l}\text { body hair, fur, } \\
\text { eyelash }\end{array}$ & nganya & NEUT & nganya \\
\hline grass (most types) & bikirra & NEUT & bikirra \\
\hline head & damangka & NEUT & damangka \\
\hline lung & jaalyakbalyaku & NEUT & jaalyakbalyaku \\
\hline smoke tree & bularraku & NEUT & bularraku \\
\hline louse & mukunjirni & FEM & mubunjini \\
\hline ibis & kunymirni & FEM & kunymirni \\
\hline $\begin{array}{l}\text { corella, white } \\
\text { cockatoo }\end{array}$ & birrili, birrilyi & FEM & birriyili \\
\hline
\end{tabular}




\begin{tabular}{|c|c|c|c|}
\hline English & Jingulu & Jingulu Gender & Mudburra \\
\hline bronzewing pigeon & marababirni & FEM & marrababirni \\
\hline hopping mouse & munyunyurni & FEM & munyinyirni \\
\hline yam type & kibilimi & VEG & kibilmi \\
\hline $\begin{array}{l}\text { wild orange tree, } \\
\text { bush orange }\end{array}$ & burnaringmi & VEG & bunayingmi \\
\hline nose & kilimi & VEG & kilimi \\
\hline $\begin{array}{l}\text { lumbar back, back } \\
\text { (lower) }\end{array}$ & barndumi & VEG & bandumi \\
\hline white currant & ngaburrayimi & VEG & ngaburrayimi \\
\hline
\end{tabular}

TABLE $11 \quad$ Final $/ \mathrm{u} / \rightarrow / \mathrm{a} /$

\begin{tabular}{llll}
\hline English & Jingulu & Jingulu gender & Mudburra \\
\hline salt, poison, medicine & lungkarru & NEUT & lungkarda \\
left (side) & wakunyu & NEUT & wakunya \\
moustache & jawulungbulungku & NEUT & jawurlungkulunga
\end{tabular}

TABLE $12 \quad / \mathrm{i} / \rightarrow / \mathrm{a} /$

\begin{tabular}{llll}
\hline English & Jingulu & Jingulu gender & Mudburra \\
\hline peewee, magpie lark & dirridirriji & MASC & dirridirrija \\
lancewood tree & karnawunji & MASC & karnawuna \\
\hline
\end{tabular}

This vowel change could be interpreted as losing the neuter suffix $-u$ and replacing it with an epenthetic /a/, which Mudburra generally does when borrowing consonant-final nouns.

This vowel change could be viewed as loss of the (old Mirndi) masculine sufix -ji in the case of 'lancewood', where Mudburra may have lost $-j i$ and added an epenthetic /a/ to avoid a consonant-final noun. However in the case of 
'peewee', Mudburra has kept the $/ \mathrm{j} /$ and then added epenthetic /a/. It is not clear why Mudburra would not simply retain *dirridirri or keep the complete form. However, bird names, particularly those with an onomatopoeic component, seem to be a law unto themselves when it comes to borrowing (Meakins and Pensalfini, submitted).

In these cases, Mudburra appears to have removed Jingulu's feminine gender suffix and replaced it with $/ \mathrm{a} /$ or $/ \mathrm{i} /$. It is not entirely clear why these forms have undergone this process while the nine forms in Table 10 ending in /rni/ have not. There appears to be no semantic rationale for this difference. For instance the word for the 'small diver duck' has undergone the process while the word for 'cormorant' has not (however note that Mudburra also uses the Jingulu form without modification as an alternative name for 'small diver duck'). The word for 'short neck turtle' shows a sophisticated understanding of Jingulu morphophonology, suggesting a high degree of bilingualism at the time of borrowing. The other two forms in the Table 13 end in an /a/ in Mudburra. We hypothesise that historically the stem in Jingulu was also (kijakija-, birrida-) and it shifted gender at some point adding -rni is added, with vowel harmony changing the final $/ \mathrm{a} /$ to $/ \mathrm{i} /$. If the stem for 'short neck turtle' were kulumandarra-, then addition of -rni would produce the Jingulu word kulumindirrirni. The fact that that form is kulumandarrirni suggests that the underlying stem is actually kulumandarri-. When -rni is added to kulumandarri-, the stem-final /i/ blocks the harmony from spreading further into the stem (Pensalfini, 2002). Mudburra speakers seem to recognise this, and thus the word surfaces in Mudburra as the bare Jingulu stem kulumandarri.

TABLE 13 Loss of feminine ending -rni

\begin{tabular}{|c|c|c|c|}
\hline English & Jingulu & Jingulu gender & Mudburra \\
\hline bull ant & kijakijirni & FEM & kijakija \\
\hline turtle (short neck) & kulamandarrirni & FEM & kulamandarri \\
\hline diver duck (small) & birridini & FEM & $\begin{array}{l}\text { birrida } \\
\text { birridini } \\
\text { birriwidi }\end{array}$ \\
\hline $\begin{array}{l}\text { itchy caterpillar, } \\
\text { 'greenfire' }\end{array}$ & burruburrurdi & FEM & burruburrurda \\
\hline masked lapwing & dirrjirrirni & FEM & dirrjirrina \\
\hline
\end{tabular}




\begin{tabular}{lllll}
\hline English & Jingulu & Jingulu gender & Mudburra & Wambaya \\
\hline stone axe & kirnbirlirdi & FEM & karnbalaja & ganybalinya
\end{tabular}

The common root in the words for 'stone axe', shown in Table 14, is kaNbala. Jingulu's feminine gender suffix (-rdi, and allomorph of -rni) triggers regressive vowel harmony, as previously described, which results in all of the low vowels in the stem raising to /i/. It could be that Mudburra has borrowed the Wambaya word rather than the Jingulu, which is why the Mudburra form lacks high vowels. In either case, Mudburra has 'undone' the gender morphology and accompanying vowel harmony: if borrowed from Wambaya, Mudburra has removed the feminine suffix -nya and replaced it with /ja/; if borrowed from Jingulu, Mudburra has removed the feminine -rdi and undone the vowel harmony, and added /ja/. Either scenario raises the question of what the Mudburra sequence $/ \mathrm{j}$ / / is doing. If the latter scenario is the case, this demonstrates a keen understanding of Jingulu morphophonology among Mudburra speakers at the time the word was borrowed, suggested a high degree of bilingualism.

Some final remaining cases are given in Table 15. We hypothesise that the Jingulu and Mudburra forms for 'axe' are actually both derived from a reduplication of "rdawu. In Mudburra, the retroflexion disappeared, while in Jingulu *rdawurdawu was reduced to $r d a r d a w u$ after Mudburra borrowed the word, but apicals are never retroflexed in initial position in Jingulu. Note that all words for axes are feminine in Jingulu. The Jingulu word for spider-web, marawunji, is identical to the Wambaya word for 'spider' (none of the other languages having a form anything like this). This has lost the sequence /nji/ in Mudburra. There is no apparent explanation for this. The masculine gender suffix in Wambaya is $-j i$, and 'spider' is indeed masculine in Wambaya. In Jingulu, however, marrunji means spider-web ('spider' is karruji) and is neuter in gender. Mudburra could be argued to have dropped a gender ending but then we would expect the resultant "marawun to take an epenthetic final /a/ to become *marawuna, as usually happens with consonant-final stems in Mudburra, rather than to drop the final $/ \mathrm{n} /$.

In general, of the 14 cases where Jingulu endings change when a word is borrowed into Mudburra, 4 are masculine $(29 \%), 3$ are neuter $(21 \%), 7$ are feminine $(50 \%)$, and none are vegetable. Mudburra removes a Jingulu masculine 


\begin{tabular}{llll}
\hline English & Jingulu & Jingulu gender & Mudburra \\
\hline axe & dardawu & FEM & dawudawu \\
web (of spider) & marawunji & MASC & marawu \\
child (crawling), & dirndijajkala & MASC & dirndij (co-verb: to \\
toddler & & & crawl)
\end{tabular}

ending $11 \%$ of the time, a neuter ending $14 \%$ of the time, and a feminine ending $37 \%$ of the time.

In summary, $85 \%(n=78)$ of 92 borrowed Jingulu nouns show no change in their form. When Mudburra does change an ending, it is most likely to remove a feminine ending. This is perhaps not unsurprising, given that feminine is a specialised (marked) gender in the superclassing system, and is also more easily segmentable from the noun stem. If this is the case, however, it is surprising is that there are no instances of nouns from Jingulu's vegetable gender, which is likewise a highly specialised and segmentable gender, having their endings removed. Nonetheless, it is worth noting that there are only 9 unambiguous instances of vegetable gender nouns being borrowed from Jingulu into Mudburra, out of a total of 92 clear borrowings (less than $10 \%$ ).

Of relevance here is the fact that no native Mudburra noun stems have acquired gender endings. This suggests that the borrowed Jingulu noun has a fossilised Jingulu gender marker, analysed in Mudburra as being part of the root. In this respect, the Jingulu nouns 'smuggled' the gender endings in as unanalysable 'trojan horse structures'.

\subsubsection{Evidence of Agreement Phenomena in Mudburra?}

Given that there is no evidence of the productivity of gender suffixes in Mudburra, i.e. the extension of Jingulu gender suffixes to native Mudburra nouns, it is unlikely that agreement phenomenon would have transferred into Mudburra. Indeed, we find no evidence of gender concord in Mudburra. For example, in the following Mudburra clauses in (6)-(8), the Mudburra adjective dija 'big' does not change its form to agree with Jingulu-origin vegetable or masculine nouns. Similarly in (9), the Mudburra demonstrative yali 'that' does not change form in agreement with the Jingulu-origin feminine noun. ${ }^{12}$

12 Thanks to Amanda Hamilton for the first three examples. All examples are referenced with the following information: Speaker (two or three letter initial), source (recording, publication) and start time in recording. The Gurindji speakers were: 
$\begin{array}{llll}\text { (6) Dijardija } & \text { kilibi } & \text { kamba-rnini } & \text { warlu-ngka } \\ \text { big.REDUP } & \text { bush.banana(v) } & \text { cook- PRES } & \text { fire-LOC }\end{array}$

(They) cook the big bush bananas in the fire. (sM: TTS1-76_11B-01: 40:31min)

(7) Dija yibilka

big water(m)

Large waterhole. (SP: PMC1-PM1-01: 0o:41 min)

(8) Kamirrinji dija duma-rni

morning.star $(\mathrm{m}) \quad$ big rise-INF

The morning star rose big. (PD: PMC1-PM1-01: 36:23min)

(9) $\quad$ Yali=ma kilwilwirni $=\mathrm{ma} \quad$ murlu-ngarnarra ngurra-ngarnarra=ma That=TOP $\operatorname{pigeon}(f)=T O P \quad$ this-DEN country-DEN=TOP

The spinifex pigeon is from all around this country. (SD: Raymond et al., 2016)

\section{$5 \quad$ Conclusions}

This paper has explored large-scale bi-directional borrowing which has taken place over numerous (at least ten) generations between a language which lacks grammatical gender (Mudburra) and one with four grammatical genders (Jingulu). These languages come from two different, but bordering, language families. Remarkably little if any morpho-syntactic diffusion has taken place between the languages, each maintaining its own structure and core morphology, for example there is no evidence of an incipient gender system developing in Mudburra $(\$ 5 \cdot 2.2)$. Nonetheless a result of the extensive borrowing, which has been in almost equal proportions in each direction, the languages now share $65 \%$ of their nouns. This paper has focused on this transfer of nouns to see how the different gender systems affect the form of loan words.

For the most part, and as the phoneme inventories and phonotactics of the two languages are very similar, loans from Jingulu into Mudburra retain their Jingulu form. The exception to this typically involve the removal of the gender suffix from Jingulu nouns in the feminine gender, which is a semantically specialised gender within the superclassing system, and one which involves the most regular and identifiable gender affixes. The recognition of these Jingulu gender affixes by Mudburra speakers attests to a high degree of bilingualism in the contact scenario. This is further evidenced by cases in which Mudburra has not only removed a Jingulu gender suffix, but also undone or mitigated the vowel harmony triggered in Jingulu by the presence of these affixes. 
Jingulu's gender system has hitherto been characterised as being both semantic and formal (Pensalfini, 2003). Mudburra nouns borrowed into Jingulu reveal the basis of the Jingulu gender system to be predominantly semantic, with the form of the word following from its semantic classification, i.e. Jingulu generally assigns a Mudburra loan to a gender on the basis of its meaning, and then modifies the ending of the word in accordance with the following principles: if the word is assigned to either the default animate masculine gender or the default inanimate neuter gender, it is not modified; if the word is assigned to one of the specialised feminine or vegetable genders, the appropriate gender suffix is added and regressive vowel harmony is triggered. Note that the animate and inanimate superclasses shape the classification of borrowed nouns to some extent, with most nouns with unexpected genders allocated to the default animate (masculine) or default inanimate (neuter) genders.

As a final comment on gender and language contact in this region of northern Australia, it is worth noting the possibility that the 'disagreement' phenomenon in Jingulu (which reveals the superclassing of the genders) may be contactrelated. Although there is no evidence of any incipient gender system in Mudburra, it is possible that contact with Mudburra may have caused the Jingulu gender system to 'weaken', permitting modifiers and demonstratives to appear without the morphology expected given the gender of their referent, but in accordance with the underlying superclassing of the system. We have not explored this here, but were the Jingulu system in an advanced state of attrition, we might expect loans to be assigned to the default genders regardless of their semantics, which, as demonstrated, is not the case. In almost all cases, the gender of borrowed nouns proceeds according to their semantics across all four genders.

\section{Acknowledgment}

Parts of this paper were presented at the Ngumpin-Mirndi Contact workshop (8-9 April 2016) and the Ngumpin-Yapa workshop (10-11 August 2017). We are grateful for feedback from David Nash, Mary Laughren, Jane Simpson, Patrick McConvell, Rebecca Green, Eva Schultze-Berndt, Mark Harvey and Rachel Nordlinger. The work was funded by an Australian Research Council Discovery Project grant (DP150101201, 2015-2017, CI Meakins and Pensalfini). Thanks to Rachel Nordlinger, Eva Schultze-Berndt, Jane Simpson, Joe Blythe and David Nash for sharing their respective unpublished Wambaya, Jaminjung, Warumungu, Jaru and Warlmanpa lexical databases. Thanks also to Claire Gourlay who coded the Wambaya, Jaminjung, Gurindji, Mudburra and Jingulu data; and Elizabeth Hall who coded the Warlmanpa, Warumungu and Jaru data. 
We have also benefitted enormously from Glenn Wightman's comprehensive species identification work in Gurindji, Mudburra, Jaminjung, Jaru and Jingulu for finding equivalences between the languages.

\section{List of Abbreviations}

\begin{tabular}{|c|c|c|c|}
\hline DAT & dative & PRES & present \\
\hline DEN & denizen & PST & past \\
\hline FEM & feminine agreement & REDUP & reduplicant \\
\hline (f) & feminine & TOP & topic \\
\hline INF & infinitive & VEG & $\begin{array}{l}\text { vegetable } \\
\text { agreement }\end{array}$ \\
\hline LOC & locative & $(\mathrm{v})$ & vegetable \\
\hline MASC & masculine agreement & - & $\begin{array}{l}\text { morpheme } \\
\text { break }\end{array}$ \\
\hline$(\mathrm{m})$ & masculine & $=$ & clitic break \\
\hline $\begin{array}{l}\text { NEUT } \\
(\mathrm{n})\end{array}$ & $\begin{array}{l}\text { neuter agreement } \\
\text { neuter }\end{array}$ & & \\
\hline
\end{tabular}

\section{References}

Aikhenvald, Alexandra Y. 2003. Classifiers: a typology of noun categorization devices. Oxford: Oxford University Press.

Alves, Mark. 2007. Sino-Vietnamese grammatical borrowing: An overview. In Y. Matras and J. Sakel (eds.), Grammatical borrowing in cross-linguistic perspective, 343-362. Berlin: Mouton de Gruyter.

Asher, R. E. 1985. Tamil. London: Croom Helm.

Bakker, Peter. 1997. A language of our own: The genesis of Michif, the mixed Cree-French language of the Canadian Métis (Vol. 10). New York: Oxford University Press.

Bentahila, Abdelali, and Eirlys Davies. 1983. The Syntax of Arabic-French CodeSwitching. Lingua 59: 301-330.

Black, Paul. 2007. Lexicostatistics with massive borrowing: the case of Jingulu and Mudburra. Australian Journal of Linguistics 27(1): 63-71.

Blythe, Joseph. 1992. Jaru dictionary. Halls Creek.

Chadwick, Neil. 1975. A Descriptive Study of the Djingili Language. Canberra: Australian Institute of Aboriginal Studies.

Corbett, Greville. 1991. Gender. Cambridge: Cambridge University Press.

Corbett, Greville. 2012. Features. Cambridge: Cambridge University Press. 
Deegan, Bonnie, Barbara Sturt, Doris Ryder, May Butcher, Stan Brumby, Gracie Long, Nora Nagarra Badngarri, Jack Lannigan, Joseph Blythe and Glenn Wightman. 2010. Jaru Plants and Animals. Darwin: Department of Natural Resources, Environment, the Arts and Sport (NREAs).

Deuchar, Margaret, Peredur Davies, Jon Russell Herring, M. Carmen Parafita Couto and Diana Carter. 2014. Building bilingual corpora: Welsh-English, Spanish-English and Spanish-Welsh. In Enlli Môn Thomas and Ineke Mennen (eds.), Advances in the study of bilingualism, 93-110. Bristol: Multilingual Matters.

Eddington, David. 2002. Spanish gender assignment in an analogical framework. Journal of Quantitative Linguistics: 49-75. doi:10.1076/jqul.9.1.49.8482.

Epps, Patience. 2006. The Vaupés melting pot: Tucanoan influence on Hup. In Alexandra Y. Aikhenvald and Robert M. W. Dixon (eds.), Grammars in contact: A Cross-linguistic typology, 267-288. Oxford: Oxford University Press.

Gardani, Francesco. 2008. Borrowing of inflectional morphemes in language contact. Frankfurt: Peter Lang.

Green, Rebecca, David Osgarby, Amanda Hamilton, Felicity Meakins and Rob Pensalfini. 2016. Mudburra to English dictionary. Elliott.

Harvey, Mark, Ian Green and Rachel Nordlinger. 2006. From prefixes to suffixes: Typological change in northern Australia. Diachronica 23(2): 289-311.

Harvey, Mark and Nick Reid. 1997. Nominal Classification in Aboriginal Australia. Amsterdam: John Benjamins.

Haspelmath, Martin and Uri Tadmor. (eds.). 2009. Loanwords in the world's languages: A comparative handbook. Berlin: Mouton de Gruyter.

Heath, Jeffrey. 1978. Linguistic diffusion in Arnhem Land (Vol. 13). Canberra: AIAs.

Jake, Janice L., Carol Myers-Scotton and Steven Gross. 2002. Making a minimalist approach to codeswitching work: Adding the Matrix Language. Bilingualism: Language and Cognition 5(1): 69-91. doi:10.1017/S1366728902000147.

Jones, Judy Marchant Dolly Bardbarriya, Eileen Raymond, Doris Roberts, Duncan McDonald, Dinah McDonald, Margaret McDonald, Candide Simard, Colleen Moerkerken, and Glenn Wightman. 2011. Jaminjung, Ngaliwurru and Nungali plants and animals: Aboriginal knowledge of flora and fauna from the Bradshaw and Judbarra/Gregory National Park area, north Australia. Darwin: Diwurruwurru-jaru Aboriginal Corporation; Dept. of Natural Resources, Environment, the Arts and Sport. Kibogoya, Adolf. 1995. Kiswahili/English code-switching: Some morphological and syntactic aspects. (PhD thesis), Lancaster University.

Kossman, Maarten. 2008. On the Nature of Borrowing in Cypriot Arabic. Zeitschrift für Arabische Linguistik 49: 5-24.

Liceras, Juana, Racquel Fernández Fuertes, Susana Perales, Rocío Pérez-Tattam and Kenton Todd Spradlin. 2008. Gender and gender agreement in bilingual native and non-native grammars: A view from child and adult functional-lexical mixings. Lingua 118: $827-851$. 
Matras, Yaron. 2007. The borrowability of structural categories. In Yaron Matras and Jeanette Sakel (eds.), Grammatical borrowing in cross-linguistic perspective, 31-73. Berlin: Mouton de Gruyter.

Matras, Yaron and Jeanette Sakel (eds.). 2007. Grammatical borrowing in cross-linguistic perspective. Berlin: Mouton de Gruyter.

McConvell, Patrick. 2009. Loanwords in Gurindji, a Pama-Nyungan language of Australia. In Martin Haspelmath and Uri Tadmor (eds.), Loanwords in the World's Languages: A Comparative Handbook, 790-822. Berlin: Mouton de Gruyter.

Meakins, Felicity. 2011. Borrowing contextual inflection: Evidence from northern Australia. Morphology 21(1): 57-87.

Meakins, Felicity, Patrick McConvell, Erika Charola, Norm McNair, Helen McNair and Lauren Campbell. 2013. Gurindji to English dictionary. Batchelor, Australia: Batchelor Press.

Meakins, Felicity and Rob Pensalfini. 2016. Gender bender: Disagreement in Jingulu Noun Class Marking. In F. Meakins and C. O'Shannessy (eds.), Loss and Renewal: Australian Languages Since Colonisation, pp. 425-450. Berlin: Mouton de Gruyter.

Meakins, Felicity and Rob Pensalfini. submitted. Holding the mirror up to converted mixed languages: two grammars, one lexicon?

Nash, David. 1997. Comparative flora terminology of the central Northern Territory. In P. McConvell and N. Evans (eds.), Archaeology and Linguistics: Aboriginal Australia in Global Perspective, 187-206. Melbourne: Oxford University Press.

Nash, David. 2003. Vocabulary of the Warlmanpa language.

Nordlinger, Rachel. 1998a. An elementary Wambaya dictionary. University of Melbourne. Melbourne.

Nordlinger, Rachel. 1998b. A grammar of Wambaya, Northern Territory (Australia). Canberra: Pacific Linguistics.

Papen, Robert A. 2003. Michif: One phonology or two. University of British Columbia Working Papers in Linguistics 12: 47-58.

Parafita Couto, M. Carmen, Munarriz, Amaia, Epelde, Irantzu, Deuchar, Margaret, and Oyharçabal, Bañat. 2015. Gender conflict resolution in Spanish-Basque mixed DPs. Bilingualism: Language and Cognition 18(2): 304-323. doi:10.1017/S136672891400011X

Pensalfini, Rob. 1999. Optional disagreement and the case for feature hierarchies. Proceedings of the Annual Meeting of the Chicago Linguistics Society, 35, 343-353.

Pensalfini, Rob. 2001. On the typological and genetic affiliation of Jingulu. In Simpson, Jane Helen, Jane Simpson, David Nash, Mary Laughren, Peter Austin and Barry Alpher. (eds.), Forty Years On: Ken Hale and Australian languages, 385-399. Canberra: Pacific Linguistics.

Pensalfini, Rob. 2002. Vowel harmony in Jingulu. Lingua, 112(7), 561-586.

Pensalfini, Rob. 2003. A Grammar of Jingulu: An Aboriginal Language of the Northern Territory. Canberra: Pacific Linguistics. 
Pensalfini, Rob. 2011. Jingulu texts and dictionary: An Aboriginal language of the Northern Territory. Canberra: Pacific Linguistics.

Poplack, Shana, Alicia Pousada, and David Sankoff. 1982. Competing influences on gender assignment: Variable process, stable outcome. Lingua 57:1-28.

Pompey Raymond, Pharlap Dixon, Sue Dixon, Shannon Dixon, Ray Dixon, Jeffrey Dixon, Janey Dixon, Elizabeth Dixon, Mark Raymond, Harold Dalywaters, Jumbo Collins, Robin Woods, Eileen Peterson-Cooper, Felicity Meakins, Rob Pensalfini and Glenn Wightman. 2018. Jingulu and Mudburra plants and animals: Biocultural knowledge of the Jingili and Mudburra people of Murranji, Marlinja, Warranganku (Beetaloo) and Kulumindini (Elliott), Northern Territory, Australia. Batchelor, Australia: Batchelor Press.

Raymond, Pompey, Shannon Dixon, Felicity Meakins and Rob Pensalfini. 2016. Jingulu-Mudburra bird poster. Batchelor, Australia: Batchelor Press.

Rosen, Nicole. 2007. Domains in Michif Phonology. (PhD), University of Toronto, Toronto.

Schachter, Paul and Fe T. Otanes. 1972. Tagalog reference grammar. Berkley: University of California Press.

Schultze-Berndt and Candide Simard. 2015. A draft dictionary of Jaminjung .

Seifart, Frank. 2012. The Principle of Morphosyntactic Subsystem Integrity in language contact: Evidence from morphological borrowing in Resígaro (Arawakan). Diachronica 29(4): 471-504.

Simpson, Jane. 2014. Draft dictionary of Warumungu. Papulu Apparr-kari Aboriginal Corporation. Tennant Creek.

Stolz, Christel. 2009. A different kind of gender problem: Maltese loan-word gender from a typological perspective. In Comrie, Bernard, Ray Fabri, Elizabeth Hume, Manwel Mifsud, Thomas Stolz and Martine Vanhove. (eds.), Introducing Maltese linguistics: Selected papers from the ist International Conference on Maltese Linguistics, Bremen, 18-20 October, 2007, 321-353. Amsterdam: John Benjamins.

Stolz, Thomas. 2012. Survival in a niche: On gender-copying in Chamorro (and sundry languages). In Martine Vanhove, Thomas Stolz, Aina Urdze and Hitomi Otsuka. (eds.), Morphologies in contact, 93-140. Berlin: Mouton de Gruyter.

Tadmor, Uri. 2007. Grammatical borrowing in Indonesian. In Yaron Matras and Jeanette Sakel (eds.), Grammatical borrowing in cross-linguistic perspective, 301-328. Berlin: Mouton de Gruyter.

Valdés Kroff, Jorge, Paola Dussias, Chip Gerfen, Lauren Perrotti and M. Teresa Bajo. 2017. Experience with code-switching modeulates the use of grammatical gender during sentence processing. Linguistic Approaches to Bilingualism 7(2): 163-198. doi:10.1075/lab.15010.val

Whiteley, Wilfred. 1967. Swahili nominal classes and English loan-words: A preliminary survey. In Gabriel Manessy (ed.), La Classification nominale dans les langues négroafricaines, 157-174. Paris: Centre National de la Recherche Scientifique. 